\title{
Application of morphometric techniques for taxonomic revision of Berabichia oratrix (Orłowski, 1985) (Trilobita, Cambrian) from the Holy Cross Mountains, Poland
}

\author{
Anna ŻYLIŃSKA \\ Faculty of Geology, University of Warsaw, \\ Żwirki i Wigury 93, 02-089 Warszawa (Poland) \\ anna.zylinska@uw.edu.pl
}

formerly of the Museum of the Geosciences Friends Association "Phacops",

Targowa 29, 90-043 Łódź (Poland)

†Adrian Kin passed away on 26.06.2012 after complications following

leukemia therapy

Jakub NOWICKI

Faculty of Geology, University of Warsaw, Żwirki i Wigury 93, 02-089 Warszawa (Poland)

q.nowicki@gmail.com

KEY WORDS

Cambrian,

Trilobita,

Ellipsocephalidae,

morphometrics,

retrodeformation,

Holy Cross Mountains,
Żylińska A., Kin† A. \& Nowicki J. 2013. - Application of morphometric techniques for taxonomic revision of Berabichia oratrix (Orłowski, 1985) (Trilobita, Cambrian) from the Holy Cross Mountains, Poland. Geodiversitas 35 (3): 505-528. http://dx.doi.org/10.5252/g2013n3a1

\section{ABSTRACT}

Detailed analysis of $c$. 900 trilobite specimens from the Cambrian Series 2 of the Holy Cross Mountains in Poland, assigned hitherto to Comluella oratrix Orłowski, 1985 and Comluella igrzycznae Orłowski, 1985, has shown that the two species constitute in fact a monospecific assemblage representing Berabichia oratrix (Orłowski, 1985). The differences pointed out in the original diagnoses are obviously caused by taphonomic processes. To test the hypothesis of a monospecific assemblage, six sagittal and exsagittal and five transverse parameters were measured and calculated for 182 best-preserved cranidia; from this dataset, 121 cranidia with the complete set of measurements were subjected to bivariate and multivariate morphometric analyses and discriminant analysis. Results of the morphometric analysis point to the significant role of tectonic deformation in the variation of the studied sample that could have led Orłowski (1985) to distinguish two separate species. Application of graphic techniques on photographs of distorted specimens lying in different directions with regard to the stress field allowed to obtain specimens statistically indistinguishable in terms of their sagittal and transverse proportions, thus confirming the tectonic overprint on the morphology of the analyzed trilobite sample. 
MOTS CLÉS

Cambrien,

Trilobita,

Ellipsocephalidae,

morphométrie,

rétrodéformation,

Monts Sainte-Croix,

Pologne.

\section{RÉSUMÉ}

Application des techniques morphométriques à la revision systématique de Berabichia oratrix (Ortowski, 1985) (Trilobita, Cambrien) des Monts Sainte-Croix, Pologne. L'analyse détaillée d'environ 900 spécimens de trilobites provenant de la Série 2 du Cambrien des Monts Sainte-Croix (Pologne), déterminés jusque-là comme Comluella oratrix Orłowski, 1985 et Comluella igrzycznae Orłowski, 1985, montre qu'il s'agit en fait d'un assemblage monospécifique de Berabichia oratrix (Orłowski, 1985). Il est certain que les différences indiquées dans les diagnoses originales sont dues à des processus taphonomiques. Pour vérifier l'hypothèse de la monospécificité de l'assemblage, six paramètres sagittaux et exsagittaux et cinq paramètres transversaux ont été mesurés et calculés pour les 182 cranidiums de suffisamment bon état de conservation. Les méthodes d'analyse morphométrique bivariée et multivariée ainsi que l'analyse discriminante ont été appliquées aux 121 cranidiums pour lesquels il a été possible d'effectuer la totalité des mesures. Les résultats de l'analyse morphométrique montrent que l'essentiel de la variation de l'échantillon étudié peut s'expliquer par la déformation tectonique, laquelle a pu amener Orłowski (1985) à distinguer deux espèces. L'application de techniques graphiques aux images de spécimens déformés différemment selon leur position par rapport au champ de tension a permis d'obtenir des spécimens statistiquement indistinguables en ce qui concerne leurs proportions sagittale et transversale. Cela confirme l'influence tectonique sur la morphologie de l'échantillon fossile étudié.

\section{INTRODUCTION}

Ellipsocephalid trilobites occurring in the Cambrian Series 2 of the Holy Cross Mountains, Poland, include two species originally assigned to the genus Comluella Hupé, 1953: C. oratrix Orłowski, 1985 and C. igrzycznae Orłowski, 1985. Following a detailed revision of the family by Geyer (1990), the genus Comluella is now restricted to trilobites in which both the frontal area and the fixigenae and palpebral lobes combined slope down anteriorly and abaxially, i.e. they possess features that exclude the studied taxa from this genus. Moreover, Geyer (1990: 127) tentatively assigned these two Orłowski's species to Ornamentaspis Geyer, 1990. This genus includes a wide variety of species from a relatively long interval spanning the Cambrian Series 2-3 boundary interval (traditional LowerMiddle Cambrian boundary interval) in different palaeogeographic areas, that are grouped into one taxon by a uniform sagittal convexity of the cran- idium, transversely convex fixigenae rising above the axial furrows and a mixed kingaspidoid and protolenoid pattern of the lateral glabellar furrows, i.e. features that also eliminate the studied species from the genus. Correct generic assignment is hindered by yet another issue. Orłowski (1985) differentiated between the two species by subtle differences in proportions, with cranidia and glabellae of $C$. igrzycznae generally relatively narrower transversely than those of $C$. oratrix. Qualitative distinguishing parameters include e.g., the presence ( $C$. oratrix) or absence $(C$. igrzycznae) of a librigenal spine. However, careful examination of specimens housed in different museum collections indicated that the absence of a librigenal spine may be an artefact resulting from poor preservation. Therefore, a supposition was made that in reality the two taxa may be conspecific and the apparent disparity of the trilobites in question is an effect of post-burial processes, i.e. fossil preservation coupled with 


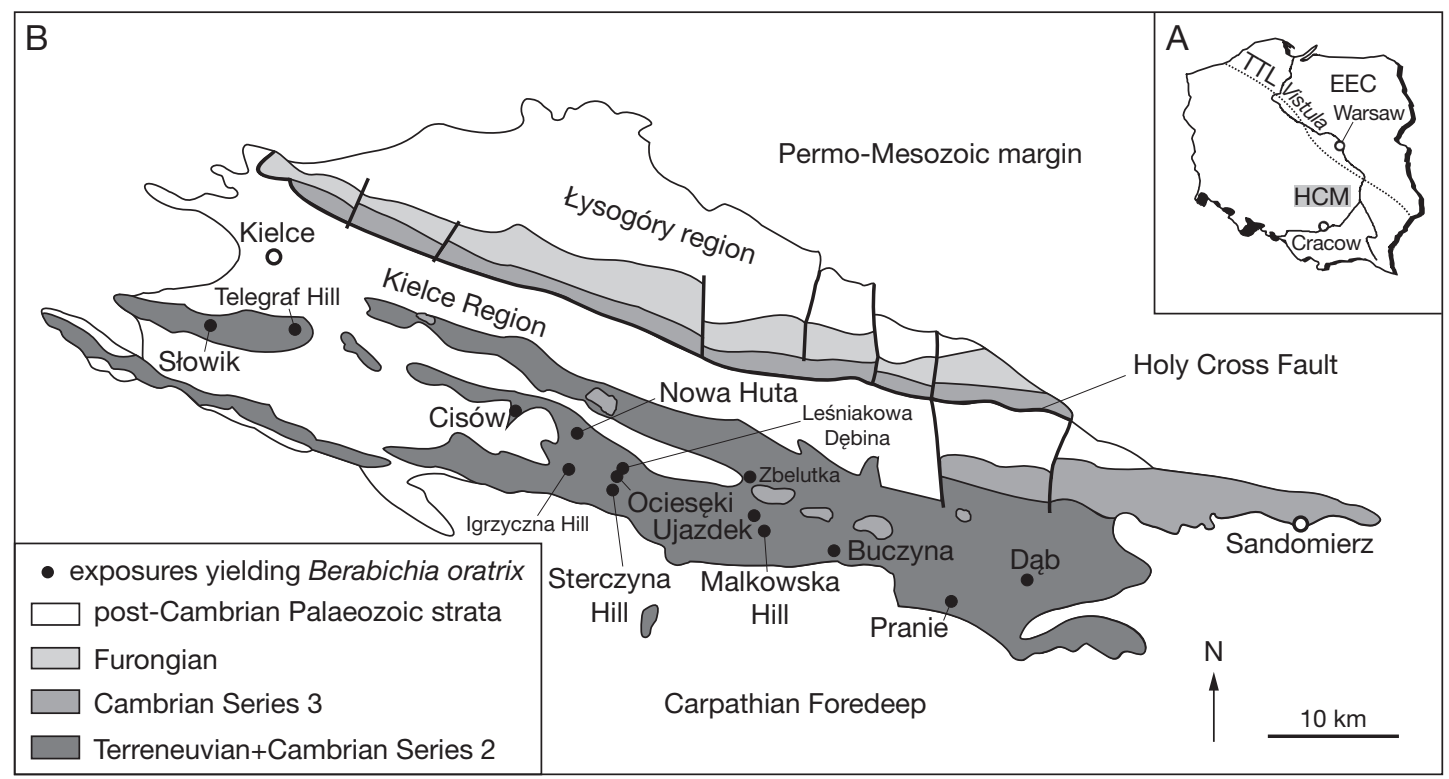

FIG. 1. - A, Sketch-map of Poland with location of the Holy Cross Mountains (HCM) in relation to the East European Craton (EEC) and the Teisseyre-Tornquist Line (TTL); B, geological sketch-map of the HCM showing the distribution of Cambrian deposits, compiled and modified from Samsonowicz (1962) and Orłowski (1975, 1992b), with location of the exposures yielding Berabichia oratrix (Orłowski, 1985).

tectonic deformations. This hypothesis was tested with bivariate and multivariate morphometric analyses and discriminant function (Hammer et al. 2001), as well as graphic techniques (Srivastava \& Shah 2006).

\section{GEOLOGICAL SETTING}

The Holy Cross Mountains (HCM) are a small hilly area in south-central Poland (Fig. 1A) located between the towns of Kielce and Sandomierz. They comprise a $c .70 \mathrm{~km}$ long and $50 \mathrm{~km}$ wide belt of Palaeozoic rocks, surrounded by the Permo-Mesozoic Margin to the west, north and east, and Miocene deposits of the Carpathian Foredeep basin to the south (Fig. 1B). One of the last major structural reorganizations of the area was the Late Cretaceous-Early Palaeogene tectonic inversion and uplift (e.g., Kutek \& Głazek 1972; Krzywiec et al. 2009) that resulted in partial removal of Permian and Mesozoic strata and exposure of the older rocks. The basement of the area belongs to the Trans-European Suture Zone, one of the main geotectonic domains in Europe (Berthelsen 1992), that separates the East European Craton from younger fold belts of Central and Western Europe. Based on different facies development, stratigraphy and tectonic evolution, the Palaeozoic rocks of the HCM are subdivided into the southern Kielce Region and the northern Łysogóry Region, separated by the WNW-ESEoriented Holy Cross Fault, and considered either as tectono-stratigraphic (e.g., Czarnocki 1919) or palaeogeographic units (e.g., Belka et al. 2000, 2002; Nawrocki \& Poprawa 2006 and references therein; Nawrocki et al. 2007) of proximal or exotic provenance.

The Cambrian of the area comprises siliciclastic facies with a total thickness estimated at 2500$3500 \mathrm{~m}$ (e.g., Orłowski 1988). All the studied specimens come from the Ociesęki Sandstone Formation exposed in the Kielce Region (Fig. 2). It is composed of fine sandstones and siltstones 
TABLE 1. - Symbols applied for the measured and calculated linear dimensions of the Berabichia oratrix (Orłowski, 1985) dataset (after Shaw 1957).

\begin{tabular}{lll}
\hline Symbol & Parameter & Measurement direction \\
\hline A1 & total cranidial length & sagittal \\
B & total glabellar length & sagittal \\
B1 & occipital-glabellar length & sagittal \\
C & palpebral length & exsagittal \\
D & occipital mid-palpebral distance & exsagittal \\
E & occipital width (calculated as B1-B) & sagittal \\
F1 & frontal area length (calculated as A1-B1) & sagittal \\
J & palpebral cranidial width & transverse \\
K & occipital length & transverse \\
K1 & palpebral glabellar width & transverse \\
$(\mathrm{J}-\mathrm{K} 1) / 2$ & width of fixigena at mid-palpebral level (calculated) & transverse \\
L & length of posterior limb & transverse \\
\hline
\end{tabular}

with claystone intercalations (Orłowski 1975) that represent shallow-marine settings as supported by sedimentary structures and ichnofossils (Studencki 1988; Orłowski 1989, 1992a; Mizerski et al. 1999; Orłowski \& Żylińska 2002). The strata in which the studied samples were collected belong to the Cambrian Series 2 Holmia-Schmidtiellus Assemblage Zone; its age is confirmed by holmiid trilobites (Czarnocki 1927, 1933; Samsonowicz 1959a; Orłowski 1985, 1987, 1988). This interval is roughly the equivalent of the Scandinavian traditional Holmia kjerulfi-group Zone (Kiær 1917; Bergström \& Ahlberg 1981; Ahlberg et al. 1986; Moczydłowska 1991; Ebbestad et al. 2003; Żylińska 2013), now considered the lower part of the H. kjerulf-'O.' linnarssoni Zone, following a recently proposed revised biostratigraphic scheme for the lower Cambrian of Scandinavia based on sequence stratigraphy (see discussion in Nielsen \& Schovsbo 2011).

\section{MATERIAL AND METHODS}

The studied specimens are preserved as internal and external moulds, as well as imprints of external moulds, and are slightly flattened. A majority of them have suffered minor tectonic distortion. Disarticulated elements of the trilobite exoskeleton prevail, dominated by cranidia. Complete specimens and thoraces are sometimes slightly enrolled.
The specimens come from a number of localities in the Kielce Region of the HCM (Fig. 1B; see also Systematic Palaeontology); the exact locality is unknown in the case of some specimens, but the lithology of the rock slabs clearly shows characteristics of the Ociesęki Formation. A total of almost 900 specimens were studied; morphometric measurements were taken from the 182 best-preserved cranidia using vernier callipers with an accuracy of $0.01 \mathrm{~mm}$. Five sagittal and exsagittal, as well as four transverse measurements were taken from each cranidium; another two were calculated from the original measurements (Table 1). A dataset comprising all measured and calculated parameters for 121 cranidia was subjected to bivariate and multivariate morphometric analyses using PAST software (Hammer et al. 2001). Photographs with a digital camera were made of individual specimens coated with ammonium chloride or rock slabs with several specimens; in the latter case, the trilobites were more distinctive by their reddish-brown colour contrasting with the surrounding light-coloured rock, therefore the rock slabs were left uncoated. Photographs of the rock slabs with several specimens were used in the graphic retrodeformation. Close-ups of uncoated individual specimens were made with a hand USB digital microscope. The names "igrzycznae" and "oratrix" used throughout refer to morphotypes that correspond to the species sensu Orłowski (1985). 
TABLE 2. - Dimensional and morphological features distinguishing "oratrix" from "igrzycznae" (after Orłowski 1985).

\begin{tabular}{|c|c|c|}
\hline & "oratrix" & "igrzycznae" \\
\hline $\begin{array}{l}\text { Dimensional features } \\
\text { glabellar width (tr) } \\
\text { glabellar length (sag) } \\
\text { occipital ring length (sag) } \\
\text { palpebral lobe length (exsag) }\end{array}$ & $\begin{array}{l}\text { exceeding fixigenal width } \\
4 / 5 \text { cranidial length } \\
\text { short } \\
\text { long, reaching posterior furrow }\end{array}$ & $\begin{array}{l}\text { much smaller than fixigenal width } \\
3 / 4 \text { cranidial length } \\
\text { long } \\
\text { poorly marked }\end{array}$ \\
\hline $\begin{array}{l}\text { Morphological features } \\
\text { librigenal spine } \\
\text { convexity of preglabellar field } \\
\text { number of thoracic segments } \\
\text { pleural spines }\end{array}$ & $\begin{array}{l}\text { long, sharp, narrow } \\
\text { medium } \\
11 \\
\text { sharp, directed backwards }\end{array}$ & $\begin{array}{l}\text { lacking } \\
\text { low or medium } \\
13 \\
\text { anterior two sharp and blunt, } \\
\text { remaining sharp and short }\end{array}$ \\
\hline
\end{tabular}

\section{VARIATION RESULTING FROM TAPHONOMY}

Morphological features distinguishing "igrzycznae" from "oratrix" (Table 2) that could be affected firstly by taphonomic processes include: the presence or absence of the librigenal spine; the convexity of the preglabellar field; the number of thoracic segments; and the shape of pleural tips.

According to the original diagnosis, "oratrix" is characterized by the presence of a long, sharp and narrow librigenal spine (Orłowski 1985: 244), whereas in "igrzycznae" the librigenal spine is absent (Orłowski 1985: 245). The base of the spine in "oratrix" was located on the librigenae at the level of $S 1$ on the glabella (Fig. 3); being relatively narrow, the spine could easily break off, resulting in specimens assigned to "oratrix" but without a librigenal spine (Fig. 4A). Moreover, the studied sample contains specimens labelled as Comluella igrzycznae, in which librigenal spines were recognized (Fig. 4B-F). The spines are rather poorly preserved and observed generally on imprints of external moulds and thus could have been easily omitted in the original study. Preservation of spines only on imprints is a common feature for the ellipsocephalids from the siliciclastic facies of the HCM and was already pointed out in recent systematic descriptions of Cambrian trilobites (e.g., Żylińska \& Szczepanik 2009). Thus, both "oratrix" and "igrzycznae" probably had librigenae with a spine that could be broken off during taphonomic processes.

The facies in which "oratrix" and "igrzycznae" are preserved comprise fine-grained, strongly bioturbated sandstones with admixture of siltstones and could undergo different styles of compaction. The preglabellar field and other convex or concave elements in the cranidium may often be affected by variable compactional deformation, resulting in taxonomic confusions and morphological misinterpretations if the compressed features are considered primary (see e.g., Webster \& Hughes 1999).

Relatively complete thoraces are rare in both morphotypes. The highest number of segments (eleven) in "oratrix" was observed only in one specimen (MWG ZI/29/1379). However, it is unclear if this is the maximal value, because the anterior and posterior parts of the specimen are too poorly preserved to allow a confident count (Fig. 5A, C). Up to thirteen thoracic segments are preserved in relatively complete specimens of "igrzycznae" (Fig. 5B, D-F). Therefore, it cannot be excluded that the total number of segments was thirteen in both morphotypes.

Orłowski (1985) stated that, contrary to "oratrix", the first two pleural spines in the thoraces of "igrzycznae" are short and blunt. Re-examination of thoraces assigned to "igrzycznae" has shown that either the specimens have narrow, backward-directed spines (Fig. 5B, E) or they lack thoracic spines due to probably taphonomic factors. 


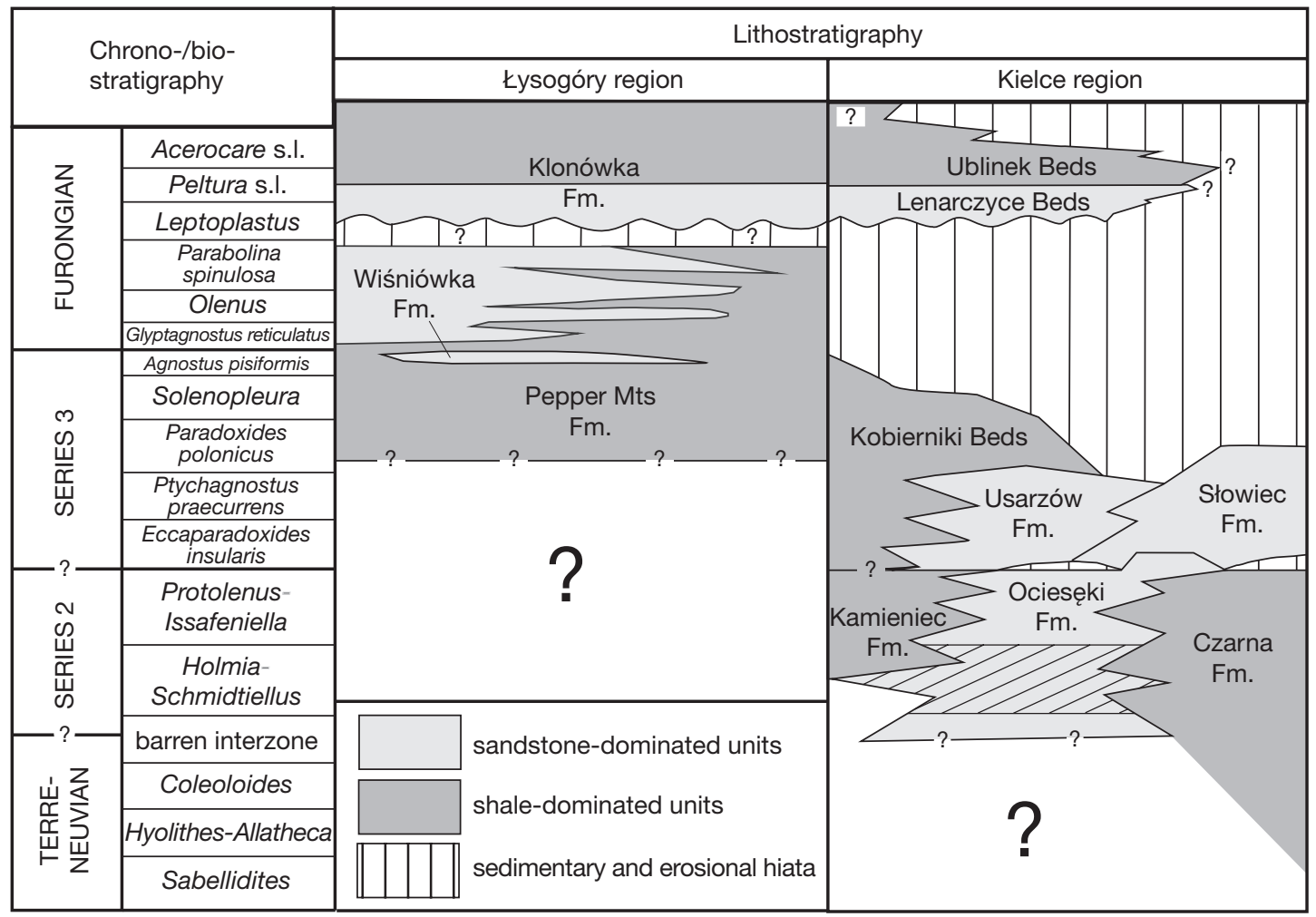

FIG. 2. - Lithostratigraphic scheme of the Cambrian in the HCM, modified after Żylińska \& Szczepanik (2009). Informal lithostratigraphic units are in italics. The stratigraphic position of the analyzed trilobites in the Ociesęki Formation is marked by diagonal lines.

\section{VARIATION RESULTING FROM TECTONIC DISTORTION}

Tectonic deformations may often change fossil morphology significantly, resulting in exaggerated intraspecific variation or even assignment of the specimens to putatively different taxa (e.g., Hughes \& Rushton 1990; Fortey \& Owens 1992; Hughes \& Jell 1992). Potentially, such situation could have occurred in the studied trilobite sample because Cambrian strata of the Kielce Region in the HCM, along with the fossils preserved in them, were subject to multiple tectonic deformations from the pre-Late Tremadocian Sandomirian phase (e.g., Gągała 2005). The studied trilobite specimens from Cisów give a good example, where a narrow (Fig. 6A-C) and a broad (Fig. 6D-F) morphotype are present. If so, then the difference in cranidial proportions between "igrzycznae" and "oratrix" are the result of various positions of the trilobite carapaces in relation to the stress field. In order to test this hypothesis, two tests were conducted: 1) morphometric measurements were subjected to statistical analysis (bivariate, multivariate, and discriminant function); and 2) digital images of the specimens were retrodeformed using a graphical method. Statistical analyses were conducted in PAST version 2.07 (Hammer et al. 2001); retrodeformation was performed using CorelDRAW( X3 software.

\section{STATISTICAL ANALYSIS}

\section{Bivariate analysis}

This method (Hughes \& Jell 1992) is commonly applied to reduce changes in the proportions of fossils caused by tectonic deformation. It compares 
pairs of parameters lying in one plane, i.e. with the same degree of deformation; therefore their mutual proportions remain unchanged. The bivariate method should generally be treated as the first step in the analysis of a tectonically deformed population.

When the observed variation in a sample is exclusively the effect of tectonic deformations, then the following properties of the variation are expected (Hughes \& Jell 1992): 1) the correlation coefficient of two perpendicular dimensions should always be lower than the correlation coefficient of parallel dimensions; 2) ratios between dimensions should be independent of size; and 3) all variation should be continuous within the sample, provided that the specimens did not attain preferred orientation prior to deformation. When any of these properties is not met, morphological variation was present in the sample prior to deformation.

To test these predictions, we prepared scatter plots for pairs of variables. The study sample generally reveals high correlation with regard to parallel parameters and much lower in the case of perpendicular parameters (Table 3). There is distinct linear relationship between particular parameters (Fig. 7A-E). Pairs of parallel parameters generally exhibit high correlation (Table 3 and Fig. 7B, C) and cannot be used to differentiate the putative species distinguished by Orłowski (1985). The only exception is the total glabellar length compared to A1-B (occipital ring width and frontal area length combined) (Fig. 7A), which indicates some allometry in the bulk sample, but again no differentiation between the putative species of Orłowski (1985). Perpendicular parameters have relatively low correlation (Table 3 and Fig. 7D, E); in this comparison the putative species of Orłowski (1985) are relatively well distinguishable. The study sample contains cranidia scattered randomly on single rock slabs (Fig. 8) so that it is assumed that the sample did not attain a preferred orientation prior to deformation.

Characteristics of the reduced major axes (RMA) for particular dimensional parameters were also determined (Table 4). They suggest allometry of some of the growth relationships, e.g., relationships which include width of fixigenae at mid-palpebral level and transverse occipital length usually show relatively

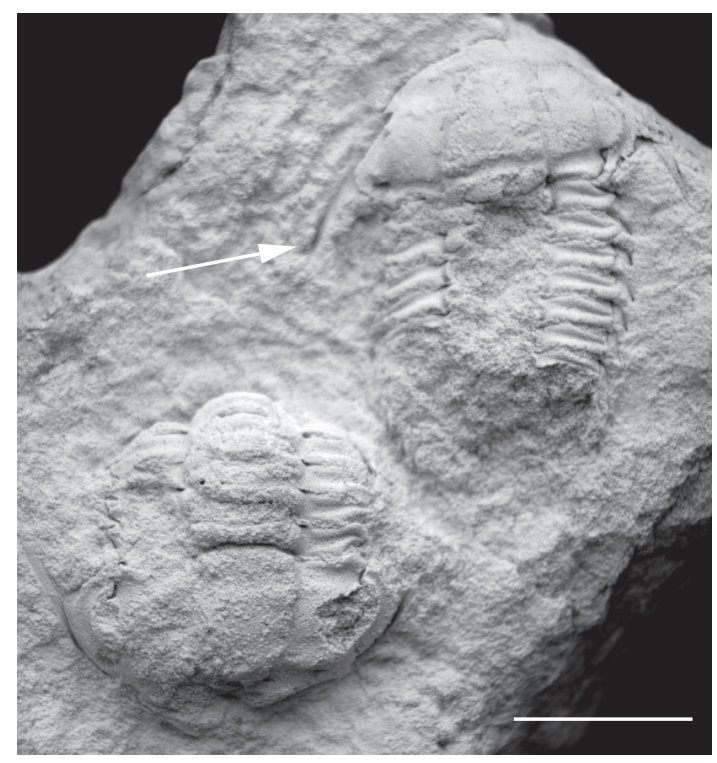

FIG. 3. - Berabichia oratrix (Orłowski, 1985), the holotype specimen is located in the upper right, original of Orłowski (1985: pl. 5, fig. 4) (MWG Zl/29/1340), from Igrzyczna Hill, HCM. Arrow, librigenal spine. Scale bar: $10 \mathrm{~mm}$.

TABLE 3. - Correlation coefficients for particular parameters in the Berabichia oratrix (Orłowski, 1985) dataset at $p<0.001$.

\begin{tabular}{|c|c|c|c|c|c|c|c|c|}
\hline & A1 & B & C & $\mathbf{J}$ & $\mathbf{K}$ & K1 & A1-B & $(\mathrm{J}-\mathrm{K} 1) / 2$ \\
\hline A1 & $x$ & 0.96 & 0.86 & 0.74 & 0.72 & 0.72 & 0.88 & 0.71 \\
\hline B & & $x$ & 0.85 & 0.74 & 0.72 & 0.73 & 0.71 & 0.70 \\
\hline C & & & $x$ & 0.67 & 0.63 & 0.67 & 0.71 & 0.64 \\
\hline $\mathrm{J}$ & & & & $x$ & 0.94 & 0.94 & 0.60 & 0.98 \\
\hline K & & & & & $\times$ & 0.95 & 0.58 & 0.88 \\
\hline K1 & & & & & & $\times$ & 0.58 & 0.85 \\
\hline A1-B & & & & & & & $x$ & 0.58 \\
\hline$(\mathrm{J}-\mathrm{K} 1) / 2$ & & & & & & & & $x$ \\
\hline
\end{tabular}

large positive or negative values of the $y$-intercept. The analysis also shows positive allometry of the total glabellar length, although not when it is compared with glabellar width at mid-palpebral level or transverse occipital length. Therefore, the assumed allometry of the sample was further tested by calculating multivariate allometric coefficients (Hammer \& Harper 2006); sagittal + exsagittal and transverse measurements were analyzed separately to exclude errors resulting from tectonic deformations. The results display that one lies well within the $95 \%$ confidence intervals 
TABLE 4. - RMA slopes and y-intercepts for selected pairs of parameters in the Berabichia oratrix (Orłowski, 1985) dataset.

\begin{tabular}{lcc}
\hline Pairs of parameters & RMA slope & RMA y-intercept \\
\hline B:C & 0.46 & 0.31 \\
B:J & 1.98 & 0.56 \\
B:(A1-B) & 0.63 & 0.09 \\
B:K & 0.86 & -0.30 \\
B:K1 & 0.76 & -0.19 \\
B:(J-K1)/2 & 0.64 & 0.19 \\
B:L & 0.56 & -0.14 \\
C:(A1-B) & 1.37 & -0.33 \\
C:J & 4.27 & -0.74 \\
C:K & 1.86 & -0.87 \\
C:K1 & 1.65 & -0.70 \\
C:(J-K1)/2 & 1.39 & -0.23 \\
C:L & 1.21 & -0.51 \\
(A1-B):K & 1.37 & -0.42 \\
(A1-B):(J-K1)/2 & 1.02 & 0.11 \\
K:K1 & 0.88 & 0.07 \\
K:L & 0.65 & 0.06 \\
K:(J-K1)/2 & 0.74 & 0.42 \\
\hline
\end{tabular}

TABLE 5. - Eigenvalues and percentage of variation for principal components obtained from the measured parameters in the $\mathrm{Be}$ rabichia oratrix (Orłowski, 1985) dataset.

\begin{tabular}{lcc}
\hline $\begin{array}{l}\text { Principal } \\
\text { component }\end{array}$ & Eigenvalue & $\begin{array}{c}\text { Percentage } \\
\text { of variance }\end{array}$ \\
\hline 1 & 6.03671 & 75.459 \\
2 & 0.896756 & 11.209 \\
3 & 0.343867 & 4.2983 \\
4 & 0.245838 & 3.073 \\
5 & 0.202025 & 2.5253 \\
6 & 0.142841 & 1.7855 \\
7 & 0.0984646 & 1.2308 \\
8 & 0.0334944 & 0.41868 \\
\hline
\end{tabular}

of the allometric coefficients for three sagittal and exsagittal (Fig. 9A) and two transverse measurements (Fig. 9B), indicating that the parameters do not show significant departure from isometry. Exceptions are: $\mathrm{K}$ (transverse occipital length) and (J-K1)/2 (width of fixigena at mid-palpebral level), which display positive and negative allometry, respectively (Fig. 9B). A slight positive allometry is also apparent for $\mathrm{B}$ (total glabellar length) (Fig. 9A). Such allometric pattern suggests that with growth the glabella became slightly longer and posteriorly wider and the fixigenae became narrower at mid-palpebral level (Fig. 10). The putative species of Orłowski (1985) can only barely be distinguished on the scatter plot.

\section{Multivariate analysis}

This method (Hughes \& Jell 1992; Hammer \& Harper 2006) characterizes the main patterns of variation in a sample, allowing the analytical removal of variation related to tectonic deformations and that resulting from isometric growth. The remaining axes of variation typically describe patterns of variation related to allometric growth and biological variation, which can be used to determine the number of taxa within the sample.

Principal Component Analysis (PCA) is a standard ordination method that constructs hypothetical variables (principal components - PCs), each a linear combination of the original variables, accounting for the highest amount of variation within the dataset. It is commonly applied in analyses of fossil data (Hammer \& Harper 2006) and has been employed in delimiting trilobite species (e.g., Hughes \& Jell 1992; Hughes 1994; Webster 2009).

Each new parameter (PC) has a series of loadings which describe its relation to original variables. Each original variable has its own loading on each PC. The score on a PC for a given specimen is calculated as the sum of values of the original variables multiplied by their loadings. In practice, each PC describes a particular pattern of variation in the dataset (as revealed by the loadings of the original variables on that $\mathrm{PC}$ ), and the relative 'importance' of that pattern of variation to the total variation within the sample is given by the per cent variance explained by that PC. The most apparent variation between the specimens is related to size, and a size-related vector is usually distinguished as the first PC (e.g., Hughes 1994); the subsequent PCs may thus represent morphological variation or that caused by tectonic deformation (Hughes $\&$ Jell 1992). Loadings of the PC corresponding to change of size during growth will have strong and positive values of all basic parameters (Hammer $\&$ Harper 2006). A PC that describes tectonic variation will be characterized by loadings of opposite sign for transverse and longitudinal original variables. Tectonic deformation, where present, typically has large impact on the observed morphological variation, and is therefore often described by one of the first PCs (Hughes \& Jell 1992). Higher PCs describe the remaining patterns of variation in the 

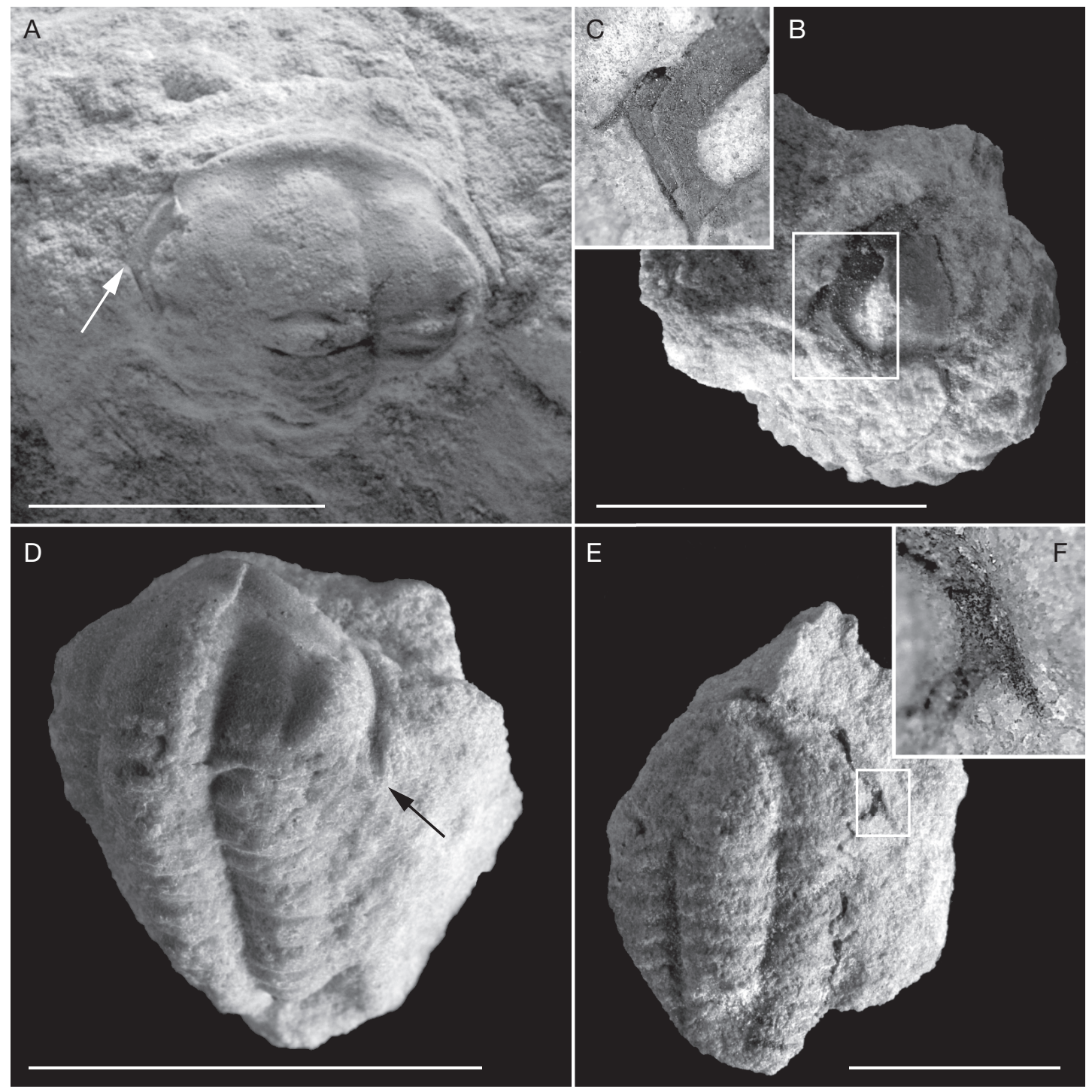

FIG. 4. - Berabichia oratrix (Orłowski, 1985): A, cephalon with fragmentary thorax, arrow points to the position of the broken-off librigenal spine (JN 006); B-F, specimens with librigenal spine, earlier identified as Com/uella igrzycznae; B, almost complete, partly enrolled specimen (MWG ZI/29/1472); C, same specimen, close-up of librigena with spine; $\mathbf{D}$, almost complete specimen, arrow points to the natural cast of the librigenal spine (MWG ZI/29/1438); E, almost complete specimen (MWG ZI/29/1471); $\mathbf{F}$, same specimen, close-up of librigena with spine. All specimens from Sterczyna Hill, HCM. Scale bars: $10 \mathrm{~mm}$.

sample, typically related to allometric growth and interspecific disparity. PCA of morphometric data is a powerful tool for identifying morphotypes that differ in shape. It should be noted that shape is only one component of morphology, and the spe- cies diagnosis should also be based on qualitative aspects of morphology.

For the PCA study of the analyzed population we selected eight parameters: the sagittal and exsagittal distances $\mathrm{B}, \mathrm{C}, \mathrm{D}, \mathrm{A} 1-\mathrm{B}$, and the transverse 

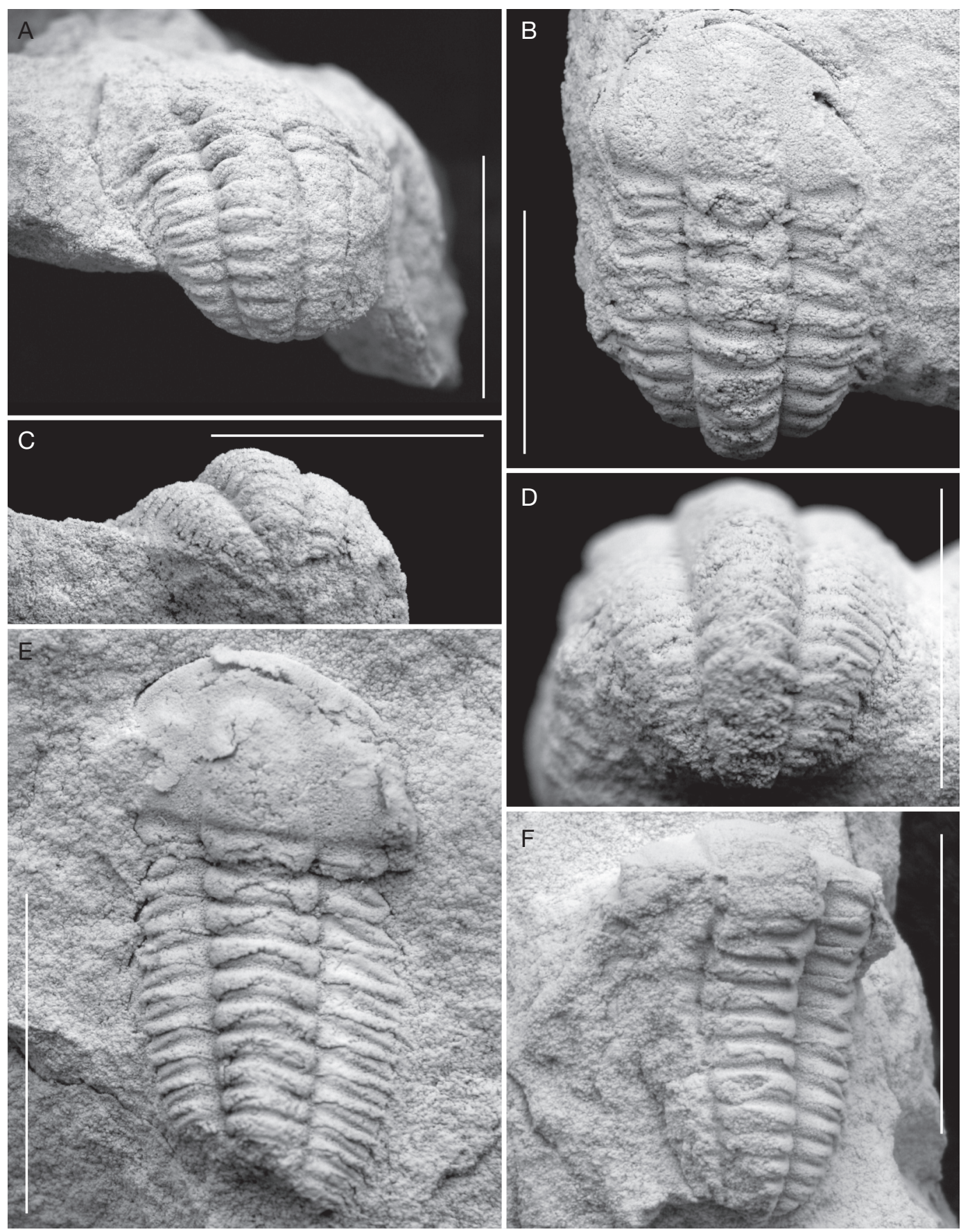

FIG. 5. - Berabichia oratrix (Orłowski, 1985): A, C, thorax from Sterczyna Hill, HCM (MWG ZI/29/1379) in dorsal (A) and lateral views (C); B, D, cephalon with thorax from Igrzyczna Hill, HCM; specimen identified earlier as the holotype of Comluella igrzycznae, original of Orłowski (1985: pl. 6, fig. 4a-b) (MWG Zl/29/1418) in dorsal (B) and lateral views (D); E, cranidium with thorax from lgrzyczna Hill, HCM; specimen earlier identified as Comluella igrzycznae, original of Orłowski (1985: pl. 6, fig. 5) (MWG Zl/29/1419), F, cranidium with incomplete thorax from Leśniakowa Dębina, HCM; specimen earlier identified as Comluella igrzycznae (MWG Zl/29/1434). Scale bars 10 mm. 

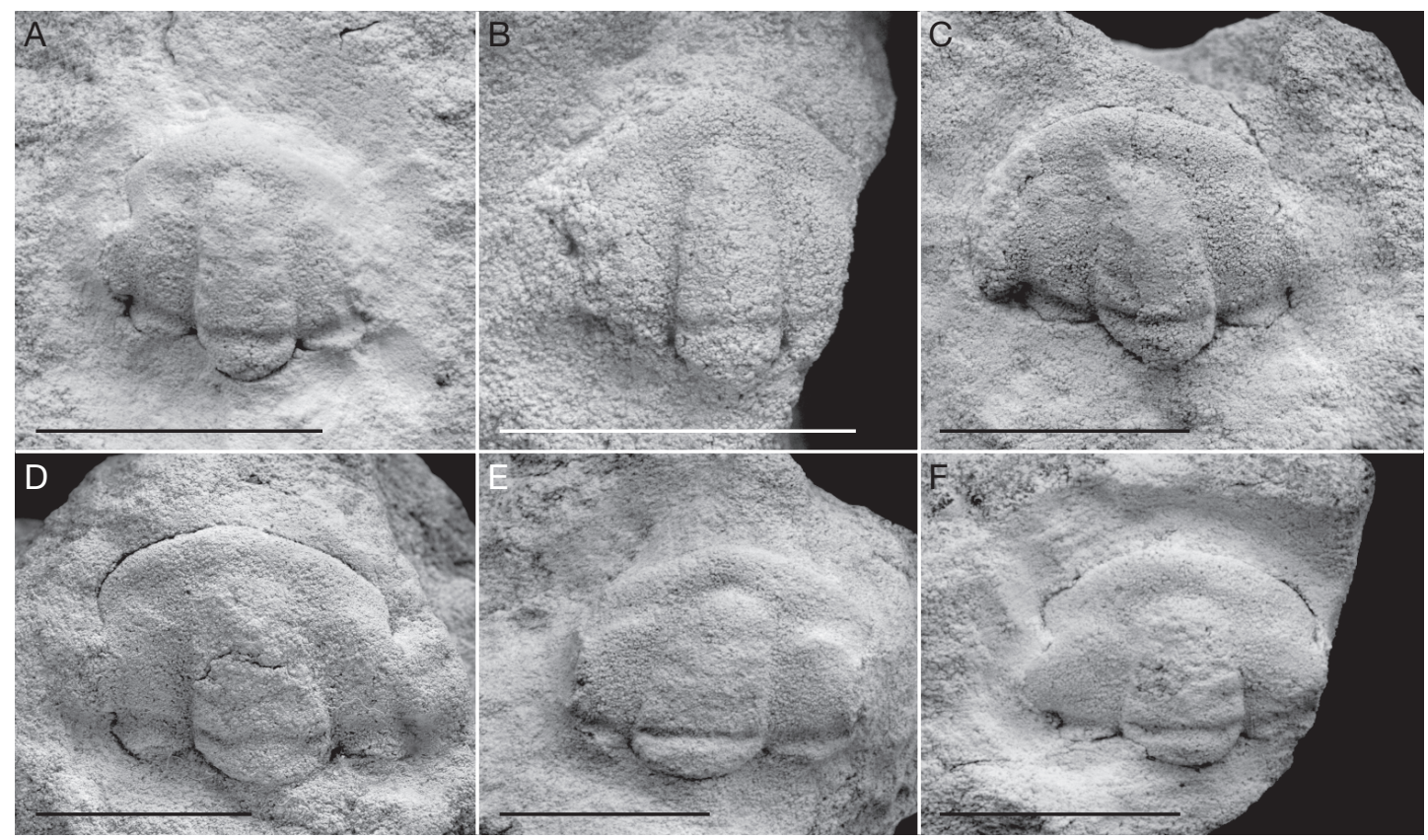

FlG. 6. - Berabichia oratrix (Orłowski, 1985) from Cisów, HCM: A-C, narrow morphotype (“igrzycznae”); A, cranidium (AK 12/TA4); B, cranidium (AK 12/TA34); C, cranidium (AK 12/TA1); D-F, broad morphotype (“oratrix"); D, cranidium (AK 12/TA16); E, cranidium (AK 12/TA23); F, cranidium (AK 12/TA22). Scale bars: $10 \mathrm{~mm}$.

distances $\mathrm{K}, \mathrm{K} 1$, (J-K1)/2, and L (see Table 1 for explanation of symbols). A correlation matrix was used in the analysis (Hammer et al. 2001). Of eight principal components, PC1 accounts for $75.46 \%$ of the total variation (Table 5 ). It has the highest score on all parameters and positive loadings of all original variables (Tables 6 and 7) and is thus interpreted as related to size in an informal sense. Differences in the loading values (Table 6) result from differences in the absolute values of parameters: among the parameters measured sagittally, $\mathrm{B}$ attains the highest values and its loading is thus the largest for these parameters, whereas A1-B has the lowest values among the parameters measured transversely and thus its loading is the smallest. Similarly, K has the highest values among parameters measured transversely (and the highest of all values) and thus attains the largest loading, and $\mathrm{L}$ has the lowest values among parameters measured transversely and attains the smallest loading. A higher percentage of total variation, reaching over
95\% was noted in populations without secondary deformations (see Hughes and Jell 1992 for relevant references). The value of variance on PC1 in the studied dataset is lower than values obtained for a tectonically deformed trilobite sample from the Himalaya (Hughes and Jell 1992). PC2 accounts for $11.21 \%$ of the variation (Table 5). It is interpreted as variation resulting from tectonic deformation of the fossils, because all dimensions have similar loadings on this PC and loadings for original variables that were measured in transverse versus longitudinal directions are of opposite sign (Tables 6 and 7). Values of PC2 for the putative species are very well correlated $(r=0.83 ; p<0.0001)$ with the $\mathrm{B} / \mathrm{K}$ ratio (Fig. 11 ), which also points to changes in the proportions of the specimens resulting from tectonic deformation. Scores and loadings of all specimens on PC1 and PC2 (Fig. 12) show that larger values of sagittal parameters lead to higher PC2 values and larger transverse parameters give lower PC2 values. Specimens assigned 
TABLE 6. - Loading values for particular parameters in relation to principal components in the Berabichia oratrix (Orłowski, 1985) dataset without standardization of variance (variance-covariance matrix).

\begin{tabular}{lccrrrrrr}
\hline & PC1 & PC2 & PC3 & PC4 & PC5 & PC6 & PC7 & PC8 \\
\hline B & 0.369 & 0.289 & -0.263 & -0.208 & -0.161 & -0.084 & -0.797 & 0.016 \\
C & 0.348 & 0.357 & -0.065 & -0.577 & 0.537 & 0.043 & 0.349 & -0.054 \\
D & 0.337 & 0.387 & -0.518 & 0.491 & -0.268 & -0.004 & 0.394 & -0.016 \\
A1-B & 0.318 & 0.421 & 0.802 & 0.261 & -0.098 & 0.038 & -0.018 & 0.012 \\
K1 & 0.681 & -0.321 & 0.055 & -0.296 & -0.411 & 0.198 & 0.189 & 0.652 \\
K & 0.286 & -0.365 & 0.067 & -0.167 & -0.317 & 0.164 & 0.092 & -0.749 \\
$(\mathrm{~J}-\mathrm{K} 1) / 2$ & 0.256 & -0.336 & 0.052 & 0.143 & 0.196 & -0.831 & 0.040 & 0.055 \\
L & 0.171 & -0.335 & -0.064 & 0.423 & 0.545 & 0.483 & -0.206 & 0.088 \\
\hline
\end{tabular}

TABLE 7. - Loading values for particular parameters in relation to principal components in the Berabichia oratrix (Orłowski, 1985) dataset with standardization of variance (correlation matrix).

\begin{tabular}{lcrrrrrrr}
\hline & PC1 & PC2 & PC3 & PC4 & PC5 & PC6 & PC7 & PC8 \\
\hline B & 90.66 & 27.36 & -15.45 & -10.29 & -7.23 & -3.19 & -25.00 & 0.23 \\
C & 85.54 & 33.85 & -3.79 & -28.60 & 24.11 & 1.63 & 10.94 & -0.99 \\
D & 82.73 & 36.62 & -30.40 & 24.34 & -12.06 & -0.2 & 12.36 & -0.30 \\
A1-B & 77.51 & 39.87 & 47.04 & 12.93 & -4.41 & 1.45 & -0.58 & 0.21 \\
K1 & 90.96 & -30.43 & 3.20 & -14.69 & -18.48 & 7.49 & 5.90 & 11.93 \\
K & 91.00 & -34.60 & 3.91 & -8.28 & -14.26 & 6.21 & 2.90 & -13.70 \\
(J-K1)/2 & 88.65 & -31.85 & 3.06 & 7.09 & 8.83 & -31.40 & 1.26 & 1.00 \\
L & 86.98 & -31.69 & -3.73 & 20.98 & 24.47 & 18.24 & -6.46 & 1.62 \\
\hline
\end{tabular}

to "igrzycznae" that have larger sagittal parameters and smaller transverse parameters are located in the upper part of the biplot, whereas specimens assigned to "oratrix" are located in the lower part of the biplot (Fig. 12). Higher PCs describe trivial proportions of the total variation in the sample and are inferred to relate to intraspecific variation (Fig. 13). The morphometric analyses demonstrate that the putative species recognized by Orłowski (1985) cannot be distinguished except along PC2, which relates to tectonic distortion so that the putative species must be regarded as tectonic variants of a single underlying morphotype and should be treated as conspecific.

\section{Additional test using discriminant analysis}

The assumption that the measured samples of "oratrix" and "igrzycznae" represent in reality one species was additionally tested with the use of discriminant analysis implemented using PAST (Hammer et al. 2001) in order to correct specimen assignment to particular species. Discriminant analysis projects a multivariate dataset onto a single axis in order to maximize separation between two a priori groups, in the studied case "oratrix" and "igrzycznae". The histogram of individuals projected onto the discriminant axis (Fig. 14) shows strong overlap of the two putative species. The parameters of the discriminant function $[v=-2.98 \mathrm{~B}+0.22 \mathrm{C}-0.96 \mathrm{D}-1.07(\mathrm{~A} 1-\mathrm{B})$ $+2.59 \mathrm{~K}+2.84 \mathrm{~K} 1-0.21(\mathrm{~J}-\mathrm{K}) / 2+1.03 \mathrm{~L}]$ are influenced mainly by parameters of the glabella, i.e. its length (B) and widths ( $\mathrm{K}$ and $\mathrm{K} 1$ ). A relatively wider and shorter glabella refers to specimens in the right part of the histogram ("oratrix" bars), whereas a relatively longer and narrower glabella refers to specimens in the left part of the histogram, occupied by "igrzycznae". The discriminant analysis indicated that $11.02 \%$ of the specimens were mis-classified; apparently they were mostly smaller specimens of "oratrix". The strong overlap of the two groups indicates that the a priori groups were not easily distinguished by the naked eye. After re-classification of the specimens to the putative species following discriminant analysis, PCA was conducted once again. The analysis failed again to support recognition of Orłowski's (1985) putative species as anything other than tectonic variants of one taxon (Fig. 15). 

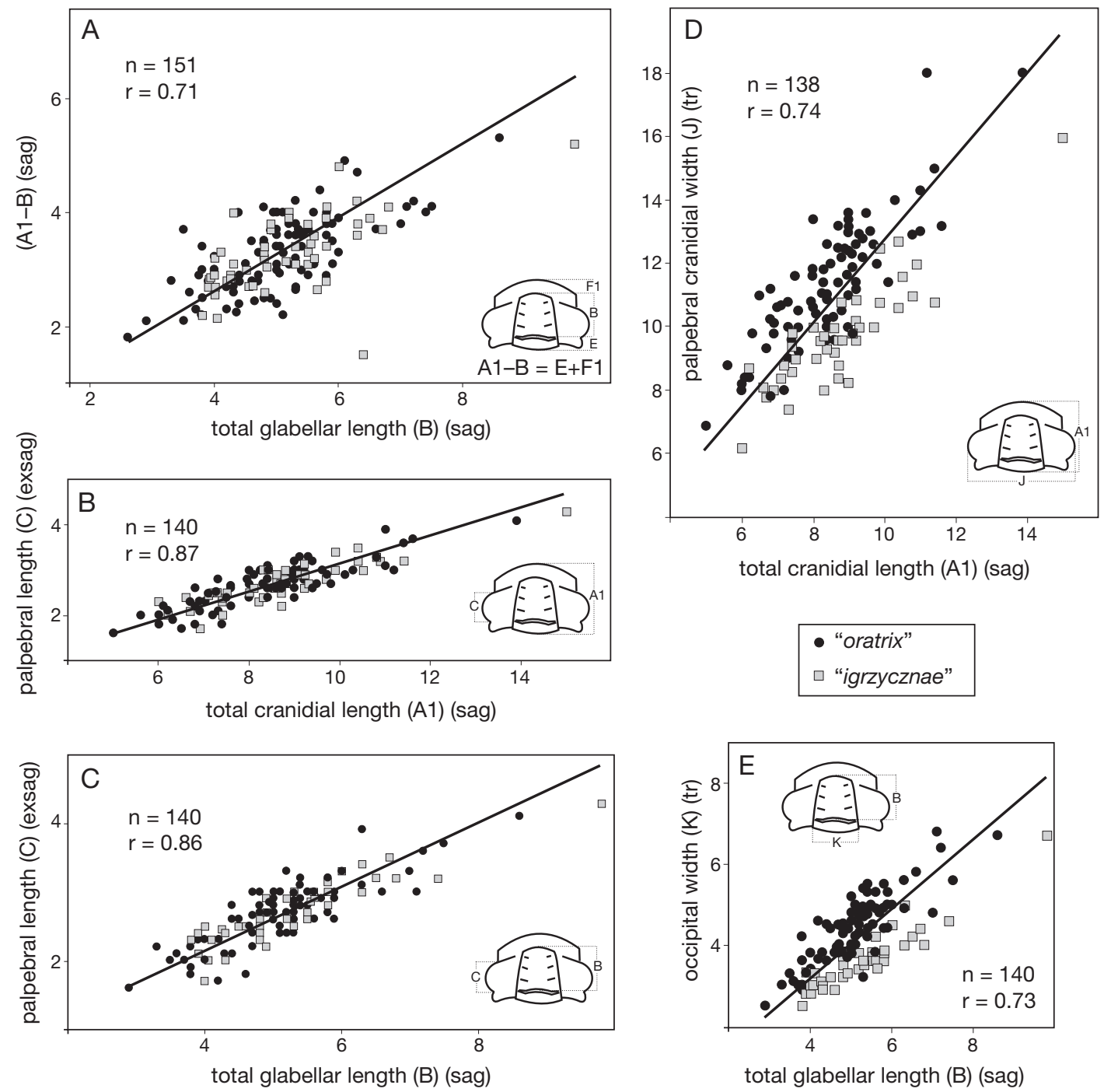

FIG. 7. - Scatter plots showing the relationships between selected sagittal, exsagittal and transverse parameters for the Berabichia oratrix (Orłowski, 1985) dataset: A, palpebral width at mid-palpebral level [(J-K1)/2] versus total glabellar length (B); B, total cranidial length (A1) versus palpebral length (C); C, total glabellar length (B) versus palpebral length (C); D, total cranidial length (A1) versus palpebral cranidial width (J); E, total glabellar length (B) versus occipital length (K). Black lines, reduced major axis; $\mathbf{n}$, number of measured specimens; $\mathbf{r}$, correlation coefficient.

\section{GRAPHIC METHOD}

Various methods of fossil restoration have been proposed since Lake (1943; see Hughes 1999 for a recent overview). Usually such techniques aim at restoring two-dimensional fossils on a bedding plane, presuming that the study area was subject to homogenous deformation (Cooper 1990).
Measurements of fossils are used to calculate the strain ellipse; its axes show the direction and proportion of distortion. The strain ellipse is recognized graphically (Cooper 1990) or by calculating the extensions in various directions (Ramsay \& Huber 1983). One of the methods applied is based on measuring a set of deformed 


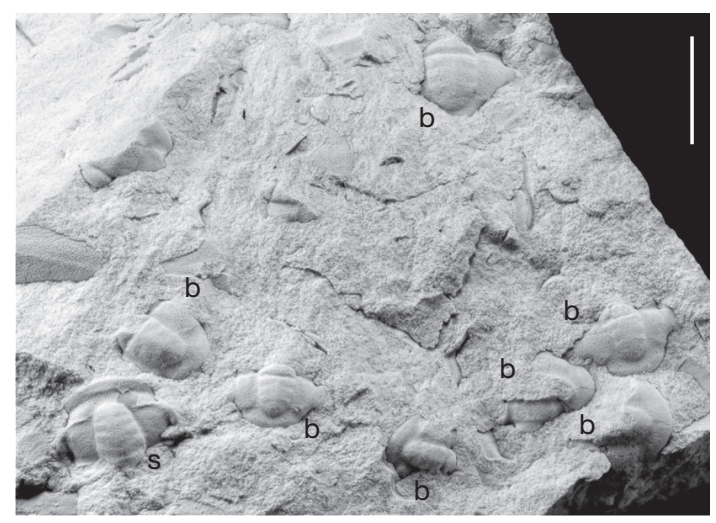

FIG. 8. - Slabs with trilobite cranidia orientated at different directions with regard to the stress field; locality unknown, HCM (MUZPIG 110.II.99); b, Berabichia oratrix (Orłowski, 1985); s, Strenuella polonica Czarnocki, 1926. Scale bar: $10 \mathrm{~mm}$. The same slab is shown retrodeformed in Fig. 16B.

angles that have been equal to one another prior to the distortion (Lake 1943; Sdzuy 1962, 1966; Cooper 1990; Rushton \& Smith 1993; Srivastava \& Shah 2006); a special case occurs when the measured angle was originally a right angle.

The graphic method of fossil restoration (Srivastava \& Shah 2006) applied in this study requires marking the axis of the specimen (or specimens) and the planes, which in an undistorted specimen should be located perpendicular to the plane of bilateral symmetry and lie at a different angle in distorted specimens. The retrodeformation technique restores the original rectangularity of planes in the specimen. In practice, such retrodeformations are conducted on photographs that are assumed to be perpendicular to the studied planes in the fossil. On the photographs the projections of the planes are straight lines and retrodeformation is based on manipulating the image in order to obtain right angles between these lines. The drawback of the method is a case when the vectors of maximal stress are parallel or normal to the symmetry axes; this will result in apparent lack of distortion. The best results are obtained when the rock slabs subject to retrodeformation techniques contain several specimens located at different directions in relation to the stress field. In effect, the retrodeformed images reveal fossils with original proportions and dimensions that can be used for taxonomic descriptions.

The studied material contains slabs that fulfil the criteria for successful graphic retrodeformation techniques (Srivastava \& Shah 2006), i.e. contains slabs with several specimens that are located obliquely to each other and at different directions with regard to the stress field (Fig. 16A, C, E). The individual specimens belong to the two morphotypes "oratrix" and "igrzycznae"; additional specimens representing Strenuella polonica Czarnocki, 1926 were also subject to retrodeformation (Fig. 16G). It is worth noting that specimens of "oratrix" and "igrzycznae" were not observed to lie parallel to one another in the examined rock-slabs. For each relatively complete trilobite cranidium a sagittal line and a transverse line at the base of the cranidium were drawn. A reference circle was also added to each image. Retrodeformation shows that the putatively distinct "oratrix" and "igrzycznae" morphotypes lose their differences (Fig. 16B, D, F) and the distorted specimens of $S$. polonica represent a sample with more uniform shapes (Fig. 16H). Thus, earlier discrimination of two species was caused by not taking tectonic deformation into account.

\section{INSTITUTIONAL ABBREVIATIONS \\ AK Museum of the Geoscience Friends As- sociation "Phacops" in Łódź [collection includes specimens collected by Katarzyna Pawłowska in 1953 in Cisów (Łobanowski 1955)];}

IGPUW JN Institute of Geology, Faculty of Geology, University of Warsaw (collection of specimens collected by JN for his M. Sc. thesis);

MUZPIG Museum of the Polish Geological Institute - National Research Institute in Warsaw (1.II, 110.II and 113.II: collections of Jan Czarnocki; 8.II: collection of Jan Samsonowicz);

MWG Museum of the Faculty of Geology, University of Warsaw (ZI/29: collection of Stanisław Orłowski; ZI/42: collection of Jan Samsonowicz);

UJ Institute of Geological Sciences, Jagiellonian University in Cracow (collection of Michał Stachacz). 


\section{SYSTEMATIC PALEONTOLOGY}

Class TRILOBITA Walch, 1771

Order REDLICHIIDA Richter, 1932

Suborder REDLICHIINA Richter, 1932

Superfamily ELLIPSOCEPHALOIDEA

Matthew, 1887

\section{REMARKS}

Assignment of the Ellipsocephaloidea to a higher level systematic rank is problematical. Many authors include them in the Redlichiina (Geyer 1990; Kaesler 1997: 429; Adrain 2011), whereas according to Fortey (1990) at least some ellipsocephaloids should be grouped among the Ptychopariina Richter, 1932 (see also Kaesler 1997: 302). Recently, Adrain (2011) suggested to abandon the suborder Ptychopariina Richter, 1932 and the order Ptychopariida Swinnerton, 1915.

Family ElLIPSOCEPHALIDAE Matthew, 1887 Subfamily ANTATLasinae Hupé, 1953

\section{Genus Berabichia Geyer, 1990}

Type species. - Berabichia vertumnia Geyer, 1990, from the Lemdad Formation (Cambrian Series 2, Sectigena Zone) in the Lemdad Syncline, High Atlas, Morocco, OD.

\section{REMARKS}

Berabichia was introduced by Geyer (1990) for three species from the Anti-Atlas and High Atlas of Morocco, i.e. B. vertumnia, the type species, B. stenometopa Geyer, 1990 and B. inopinata Geyer, 1990, and six additional morphotypes in open nomenclature. Berabichia inopinata, differing from most of the remaining Moroccan taxa included in Berabichia in a rather homogenous overall convexity of the cephalon (Geyer 1990), was subsequently transferred to the genus Epichalnipsus Geyer, Popp, Weidner \& Förster, 2004 (Geyer et al. 2004). A suggestion was made (Jell \& Adrain 2003: 348, 436) that Berabichia is a junior subjective synonym of Ptychoparopsis
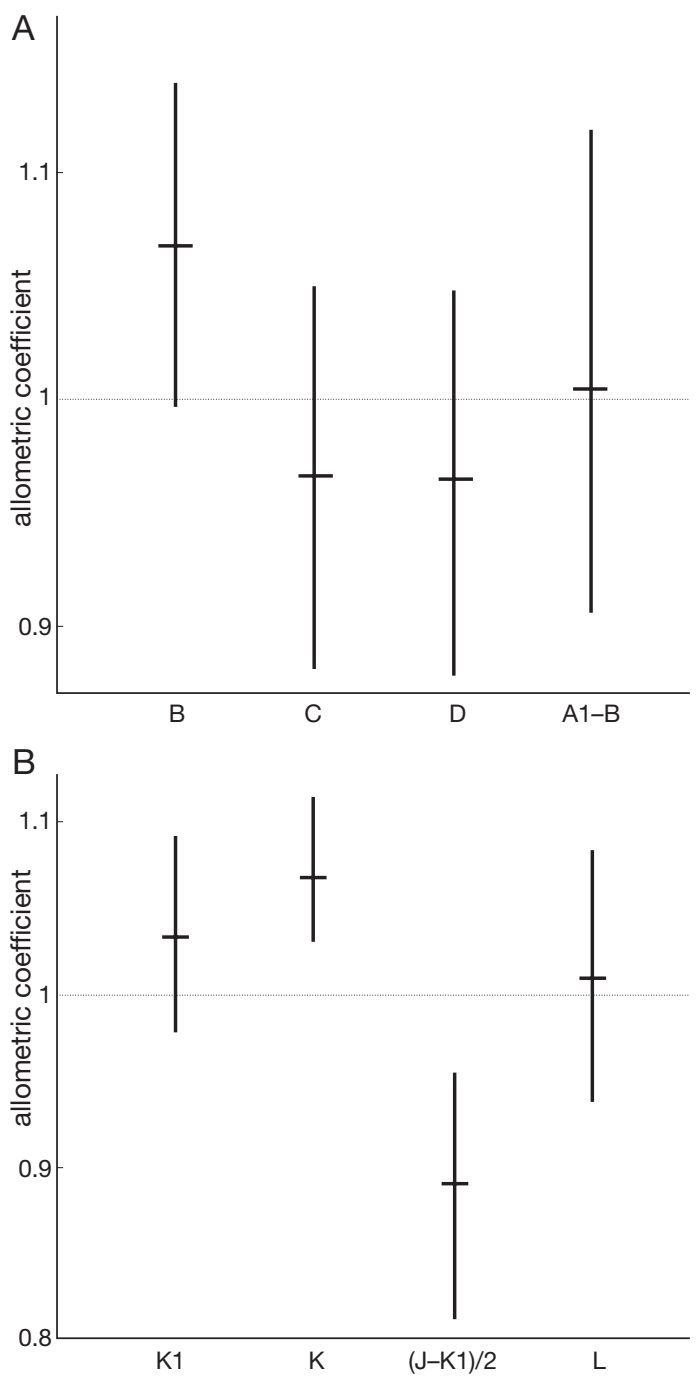

FIG. 9. - Multivariate allometric coefficients for the Berabichia oratrix (Orłowski, 1985) dataset: A, for sagittal parameters; B, for transverse parameters. For each variate, the $95 \%$ confidence interval is indicated by a vertical line. The allometric coefficient is shown by a horizontal line within the confidence interval.

Hupé, 1953. However, as pointed out by Geyer (1990), Ptychoparopsis is an unrecognizable taxon. Thus, Berabichia and Ptychoparopsis cannot be synonymized because no direct equalization has ever been proposed (G. Geyer, pers. comm.).

The Berabichia group includes also Chorbusulina wilkesi Palmer \& Gatehouse, 1972 and Chorbusulina subdita Palmer \& Gatehouse, 1972 from 


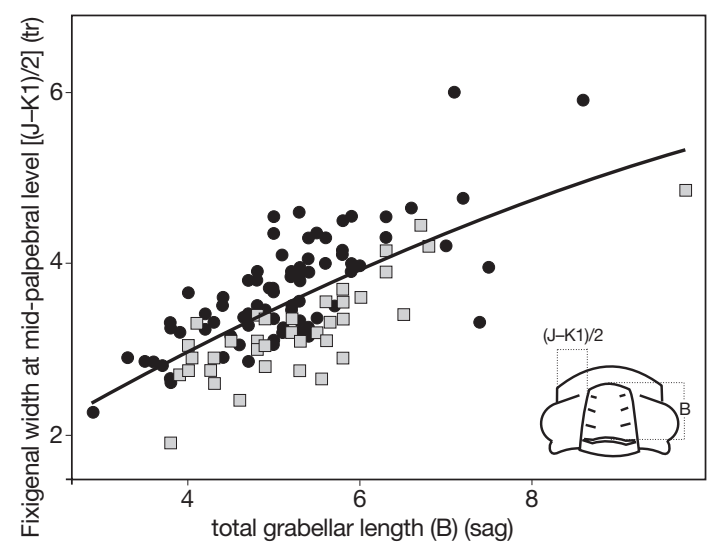

FIG. 10. - Scatter plot showing the relationship between total glabellar length (B) and fixigenal width at mid-palpebral level [(J-K1)/2] for the Berabichia oratrix (Orłowski, 1985) dataset; note slight allometry of the sample recording narrowing fixigenae in ontogeny. The exponential function $\left[y=-0.01765 x^{2}+0.655 x+\right.$ 0.6173 ] is based on a least-squares criterion and singular value decomposition, with mean and variance standardization for improved numerical stability (after Hammer et al. 2001).

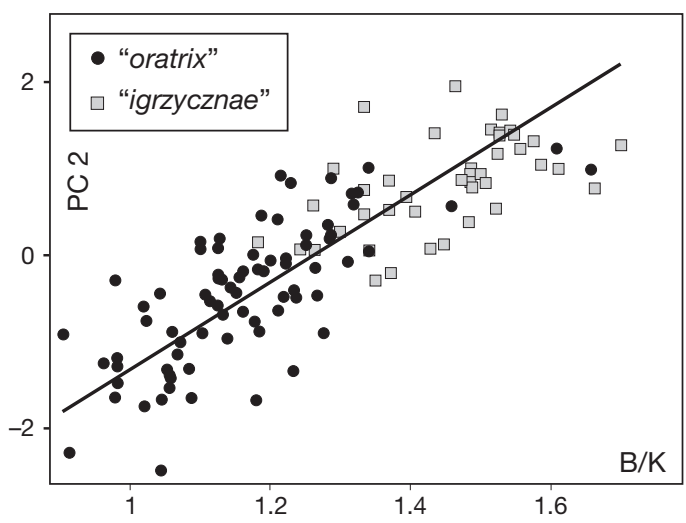

FIG. 11. - Scatter plot showing correlation between the $B / K$ ratio and the PC2 values for the Berabichia oratrix (Orłowski, 1985) dataset. Black line is the reduced major axis.

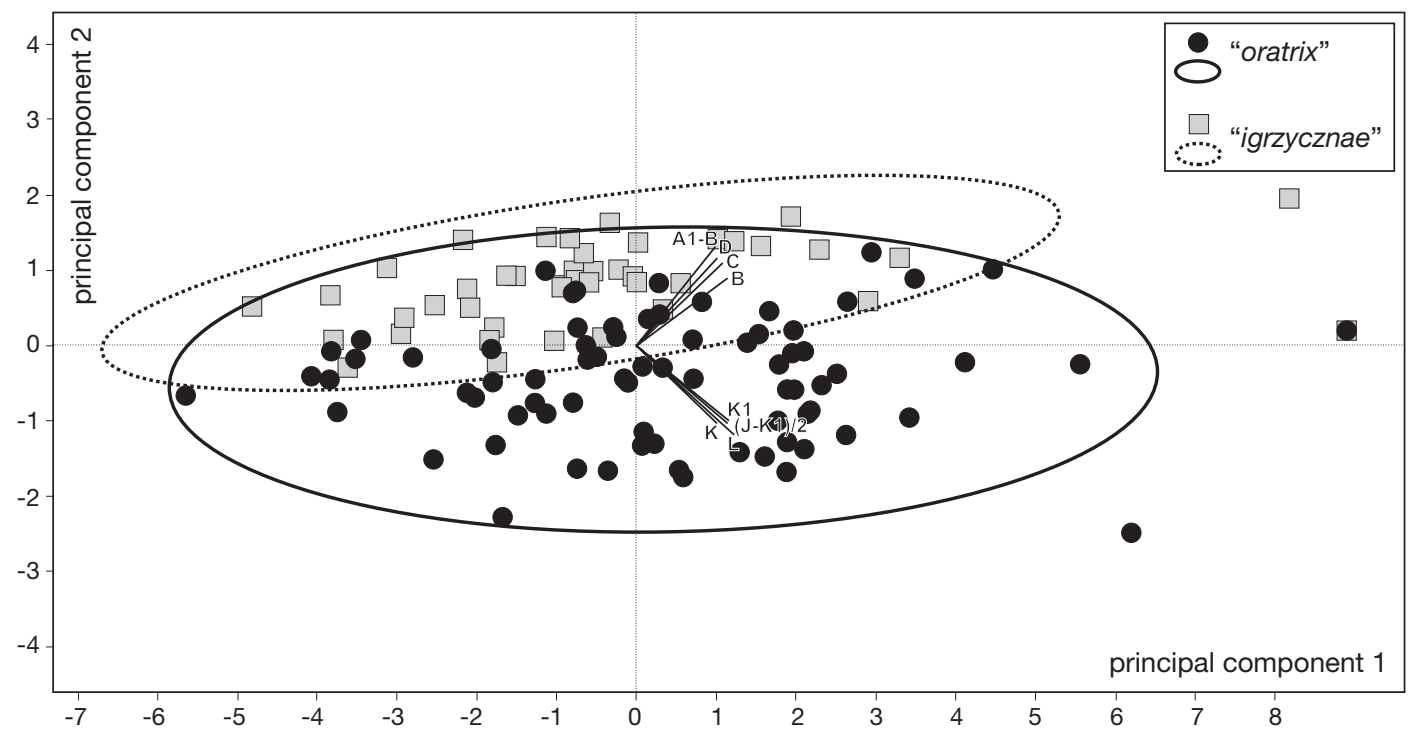

FIG. 12. - Biplot of scores and loadings on PC1 and PC2 of the Berabichia oratrix (Orłowski, 1985) dataset. PC1 is interpreted as a size axis, PC2 as a width/length difference axis. The lines represent loadings on each parameter. Ellipses mark the area of the $95 \%$ confidence interval.

the Lower Cambrian of the Argentina Range, Antarctica; Proampyx rotundatus (Kiær, 1917) from the Lower Cambrian of Sweden; and Berabichia erratica Geyer, Popp, Weidner \& Förster,
2004 from Pleistocene erratic boulders collected in a gravel pit in northern Germany (Palmer \& Gatehouse 1972; Geyer 1990; Palmer \& Rowell 1995; Geyer et al. 2004). Geyer (1990: 79) 

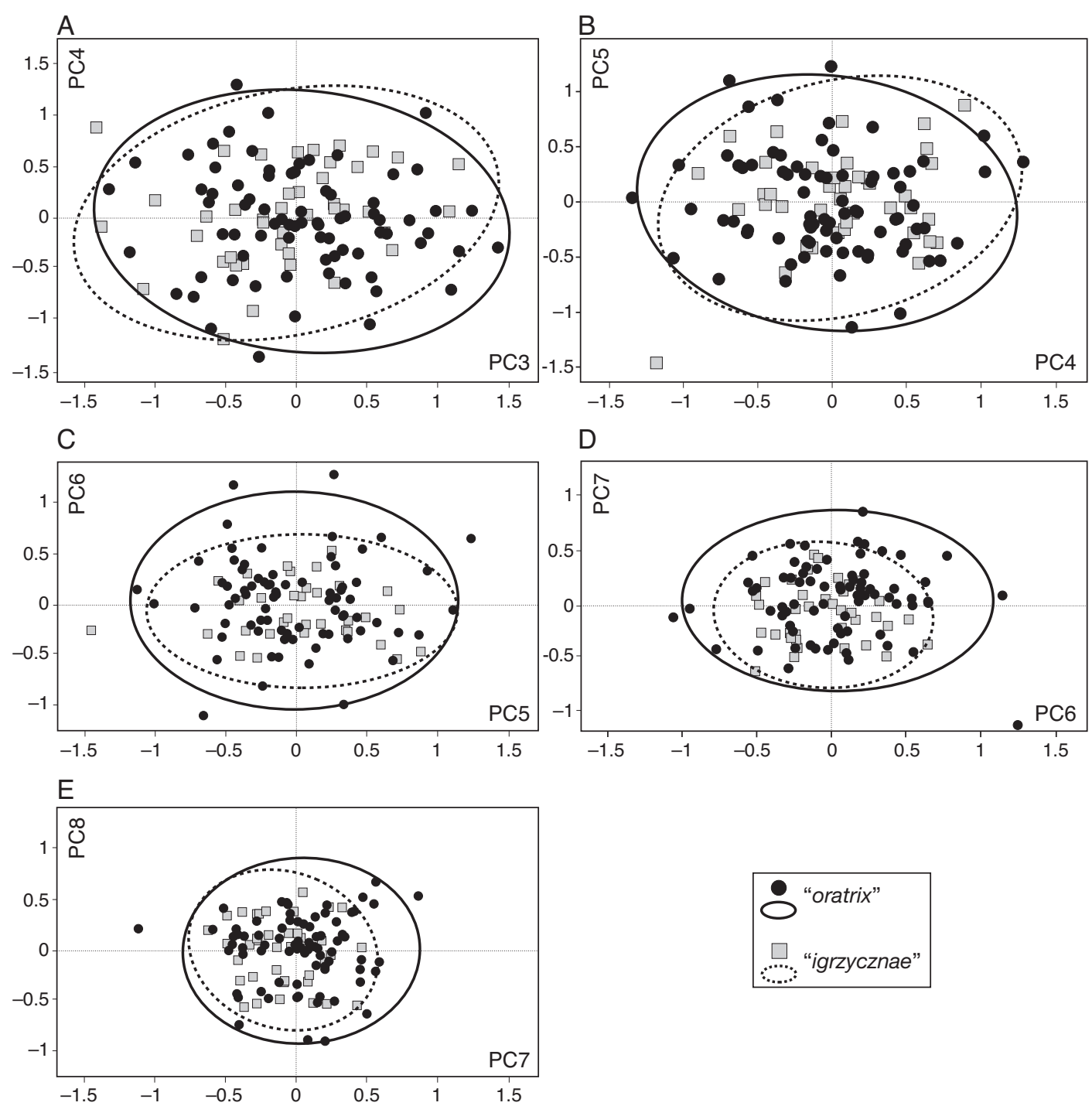

FIG. 13. - Scatter plots showing the relationships between principal components for the Berabichia oratrix (Orłowski, 1985) dataset: A, PC3 and PC4; B, PC4 and PC5; C, PC5 and PC6; D, PC6 and PC7; E, PC7 and PC8. Ellipses mark the area of the 95\% confidence interval. PC3 to PC8 shown on the plots correspond to morphological variation and are devoid of variation resulting from size (PC1) and width/length difference (PC2).

suggested that Strenuaeva kiaeri Samsonowicz, 1959 (Samsonowicz 1959b: pl. 1, fig. 16a-c; Ellipsocephalus kiaeri of Orłowski 1985: 239, textfig. 7, pl. 7, fig. 2) from the Protolenus-Issafeniella Zone of the HCM can be tentatively assigned to Berabichia; however, the only known speci- men is strongly effaced, has very shallow lateral and axial furrows and might represent a tectonic variant of Issafeniella orlowinensis (Samsonowicz, 1959b) from the same interval (see Żylińska \& Masiak 2007 and Żylińska \& Szczepanik 2009 for comparison). 


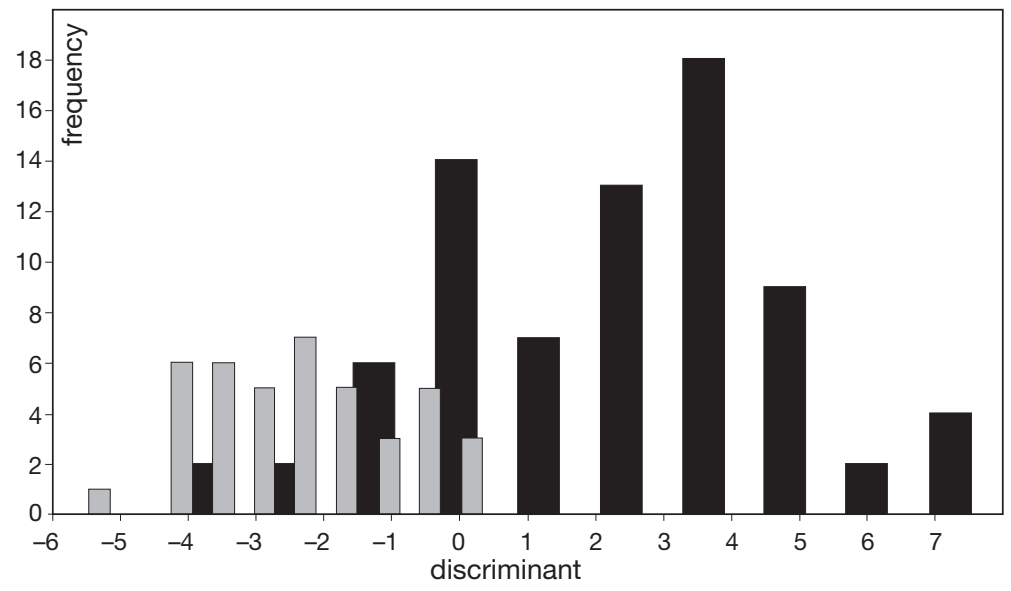

FIG. 14. - Histogram of discriminant projection values for the "igrzycznae" (grey bars) and "oratrix" (black bars) morphotypes. The cut-off point at $\mathrm{v}=0$ separates "igrzycznae" $(\mathrm{v}<0)$ from "oratrix" $(\mathrm{v}>0)$.

Berabichia oratrix (Orłowski, 1985)

(Figs 3-6; 8; 16A-F; 17)

Comluella oratrix Orłowski, 1985: 244, text-fig. 14, pl. 5 , figs 1-7, pl. 7, fig. 9.

Strenuaeva primaeva - Samsonowicz 1959b: 521, pl. 1, figs 1-9; 1962: 11, pl. 2, figs 1-4; 6-7, pl. 3, figs 3; 5 .

Termierella sandomirensis - Samsonowicz 1962, pl. 1, fig. 7 only.

Comluella igrzycznae Orłowski, 1985: 245, text-fig. 15, pl. 6, figs 1-6.

Ornamentaspis? oratrix - Geyer 1990: 127.

Ornamentaspis? igrzycznae - Geyer 1990: 127.

HolOTYPE OF COMLUELLA ORATRIX. - External mould of a cephalon with incomplete thorax (MWG ZI/29/1340; former number of the Institute of Geology collection: 1.607), figured by Orłowski (1985: pl. 5, fig. 4), illustrated herein in Figure 3.

Holotype of COMLUELLA IGRZYCZNAE. - External mould of cephalon with thorax (MWG ZI/29/1418; former number of the Institute of Geology collection: 1.301), figured by Orłowski (1985: pl. 6, fig. 4a, b), illustrated herein in Figure 5B, D.

Type locality And TYPe STRATUM. - Igrzyczna Hill, HCM; Holmia-Schmidtiellus Assemblage Zone, Cambrian Series 2 (middle part of the traditional Lower Cambrian).
AgE AND OCCURRENCE. - Berabichia oratrix is known from the Holy Cross Mountains, Poland, from the Holmia-Schmidtiellus Assemblage Zone, Cambrian Series 2 (Samsonowicz 1959b; Orłowski 1985).

EMENDED DiAgnosis. - A species of Berabichia with glabella $c .40 \%$ of palpebral cranidial width; front rounded to bluntly sub-triangular; occipital ring sagittally of slightly less than $20 \%$ of cephalic length; maximum fixigenal width slightly less than $60 \%$ of posterior glabellar width; palpebral lobes slightly more than $30 \%$ of cephalic length. Librigena with relatively long and slender spine.

Material EXAMINED. - 14 complete specimens, four cranidia with thoraces, eight thoraces, five cephala, over 840 detached cranidia, three detached librigenae; MWG ZI/29/1103, 1105, 1260, 1263, 1340-1483, 1514, 1526, 1530, 1569; MWG ZI/42/007, 021, 023, 067-072, 074-078, 081-089, 094, 100, 173, 178, 179, 182-188, $190,191,193,195-198,200,201,204,205,207-214$, 216-218, 220, 223, 224, 227-233, 235-243, 252, 264 , 267-272, 274-288; MUZPIG 1.II.8B, 23, 38, 42-45, 57, 59, 63, 64, 68, 73, 80, 85-89; MUZPIG 110.II.37, $38,56,62,68,70-72,77,78,82,86,93,95-99,102$, $105,108,110,115-123,126,130,133,135,141-146$, $150,151,155-159,164,166,170-174,176,177,180$, 182-184, 186, 188-203, 205, 213, 219, 229-231, 235; MUZPIG 113.II.2, 4, 8, 37; MUZPIG 8.II.30, 31; AK 300/CD 20-1, 12/TA 1-38; UJ 214P/T5, 6, 11, 12, 20, 23, 25; JN 033-043, 045-086. All specimens come from the local Holmia-Schmidtiellus Assemblage Zone of Cambrian Series 2 at Słowik, Telegraf Hill, Cisów, Nowa Huta, Igrzyczna Hill, Leśniakowa Dębina, Ociesęki, Sterczyna Hill, Zbelutka, Ujazdek, Malkowska Hill, Buczyna, Pranie, and Dąb, Holy Cross Mountains, Poland. 
MeAsurements. - Cranidial length 4.4-13.9 mm, cranidial width across centre of palpebral lobes 5.8-18 $\mathrm{mm}$. The holotype cranidium is $8 \mathrm{~mm}$ long and $10 \mathrm{~mm}$ wide across centre of palpebral lobes.

\section{DESCRIPTION}

Cephalon semi-elliptical, overall convexity relatively low; length $127 \pm 18 \%$ of palpebral cranidial width $(\mathrm{n}=138)$. Glabella slightly elevated above the fixigenae, defined by distinct furrow, 78 $\pm 4 \%$ of cephalic length $(n=151)$ and $39 \pm 4 \%$ of palpebral cranidial width $(\mathrm{n}=135)$. Glabella tapering forwards, with rounded to bluntly subtriangular front. Three pairs of rather shallow, slightly backwardly directed lateral glabellar furrows. Occipital furrow narrow and deep, slightly sinuous. Occipital ring $17 \pm 3 \%$ of cephalic length $(\mathrm{n}=151)$. Occipital node or spine not developed. Fixigenae $67 \pm 7 \%$ width of occipital ring (n $=123), 29 \pm 3 \%$ of cephalic length $(\mathrm{n}=121)$ and $57 \pm 3 \%$ of posterior glabellar width. Ocular ridges indistinct, straight, slightly backwardly directed, visible on the shell exterior only, located at level of S3 and separated from glabella by narrow furrows. Palpebral lobes $32 \pm 3 \%$ of cephalic length $(\mathrm{n}=140)$, strongly convex, reaching from ocular ridges to posterior border furrows. Palpebral furrow a shallow depression, narrower anteriorly and distinctly widening posteriorly. Palpebral lobes slightly upturned posteriorly. Frontal area $22 \pm 4 \%$ of cephalic length $(n=147)$, entire, distinctly convex, without border furrow.

Librigena nearly flat, its width is less than onethird of transverse cranidial width across palpebral lobes, with sharp and slender librigenal spine whose base is at level of S1; librigenal spine slightly divergent from lateral margin, reaching to the level of the posterior part of second thoracic segment. In some cases, the spine is visible only on imprints of external moulds. Inner spine angle nearly rectangular. Librigenal border relatively wide and flat, separated from genal field by narrow furrow.

Thorax composed of up to 13 segments narrowing posteriorly, pleurae with distinct, long furrows, extending into backward-directed spines.

Pygidium small, sub-triangular, wider than long, axial piece strongly convex, reaching to posterior margin.
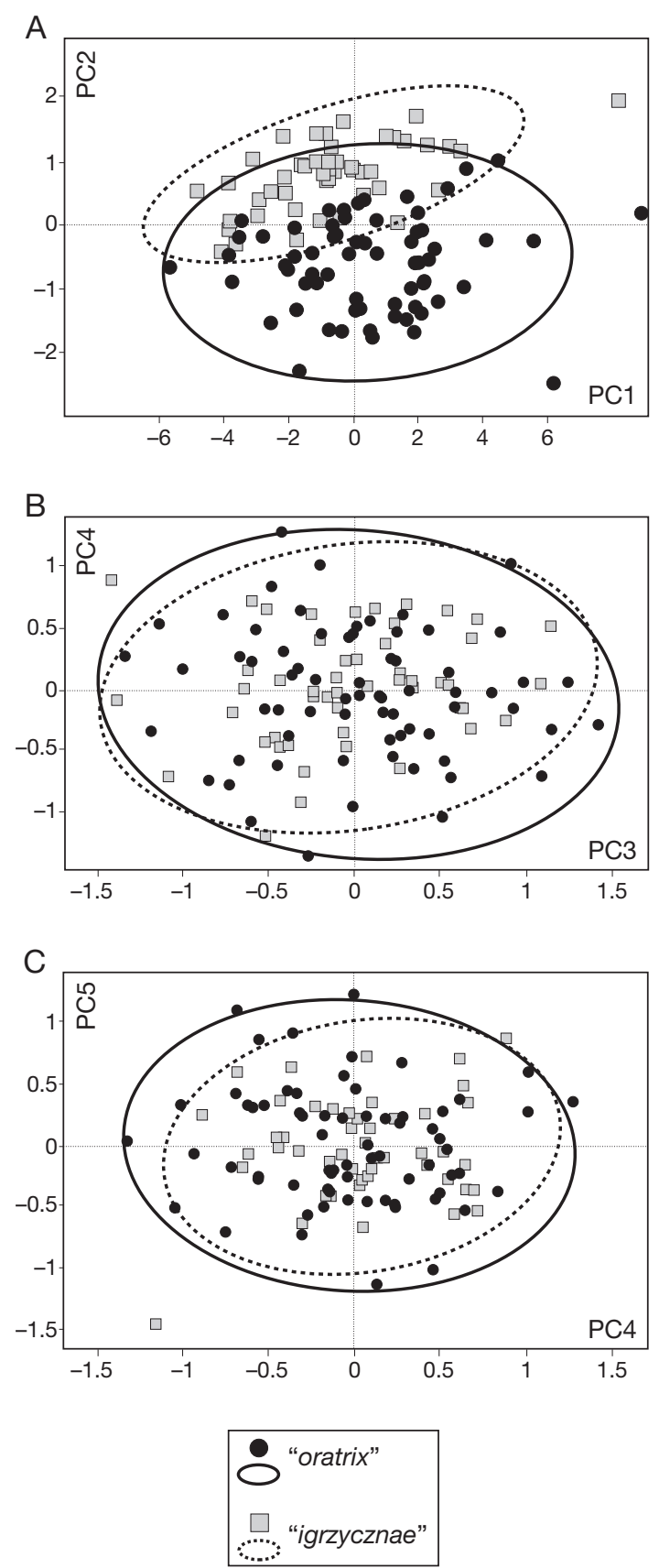

FIG. 15. - Scatter plots showing selected relationships between principal components for the Berabichia oratrix (Orłowski, 1985) dataset after discriminant analysis: A, PC1 and PC2; B, PC3 and PC4; C, PC4 to PC5. The ellipses mark the area of the $95 \%$ confidence interval. 

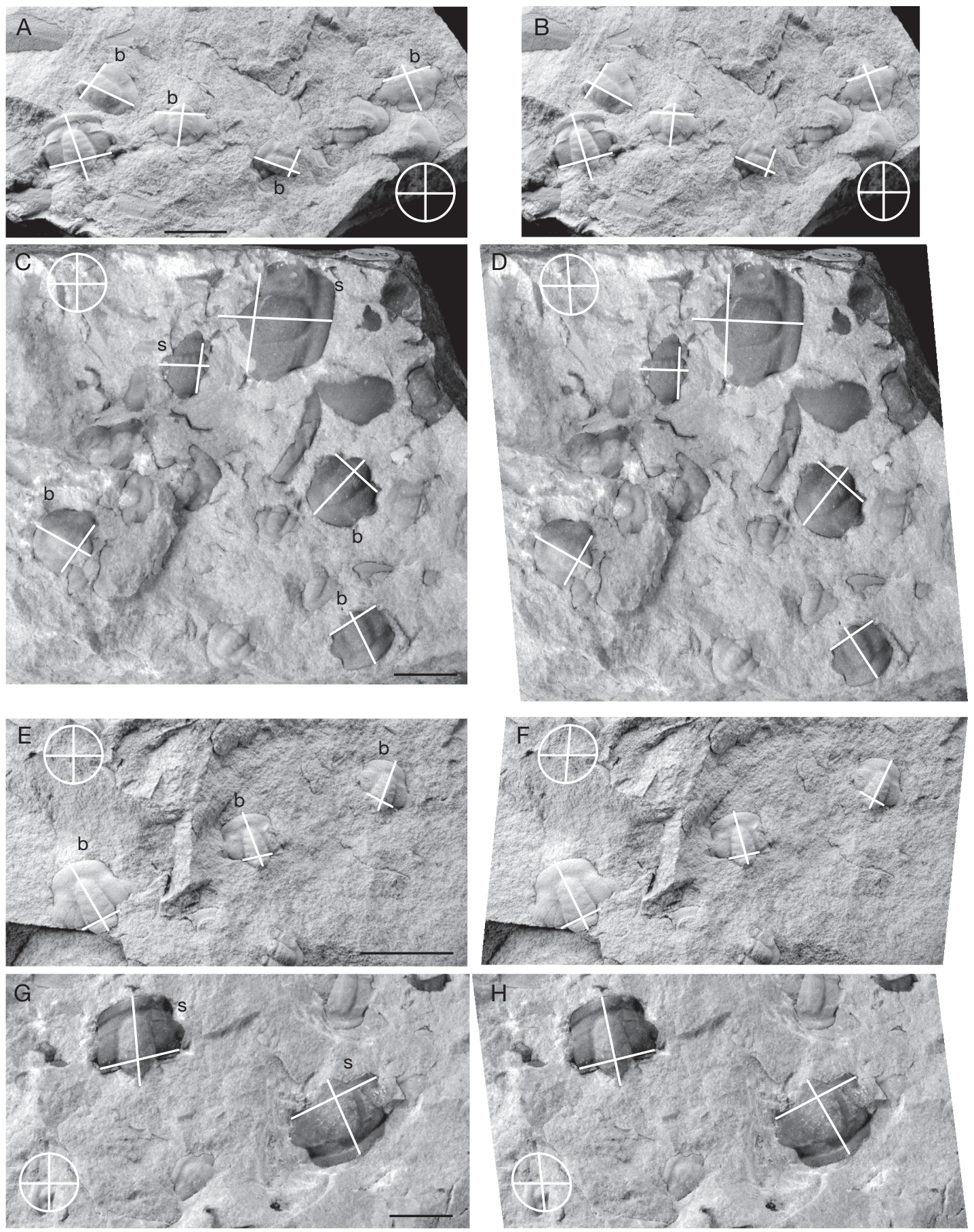

FIG. 16. - Slabs with trilobite cranidia located in different positions with regard to the stress field as preserved (A, C, E, G) and after retrodeformation (B, D, F, H); A, B, locality unknown, HCM (MUZPIG 110.II.99); C, D, Leśniakowa Dębina, HCM (MUZPIG 1.II.87); E, F, locality unknown, HCM (MUZPIG 110.II.173); G, H, Leśniakowa Dębina, HCM (MUZPIG 1.Il.86). White circle is the reference circle, white ellipse is the strain ellipse. Abbreviations: b, Berabichia oratrix (Orłowski, 1985); s, Strenuella polonica Czarnocki, 1926. Scale bars: $10 \mathrm{~mm}$. 


\section{REMARKS}

Assignment of this species to Berabichia Geyer, 1990 rather than Ornamentaspis Geyer, 1990 as tentatively suggested by Geyer (1990: 127) is justified by several cranidial features that include: a relatively flat cranidium with a tapering forwards glabella that has a rounded or bluntly sub-triangular anterior lobe, slightly upturned palpebral lobes, and a convex and entire frontal area; the lateral glabellar furrows in the studied specimens are oblique backwards, as in most species assigned to Berabichia, whereas in Ornamentaspis they attain a mixed kingaspidoid and protolenoid pattern (Geyer 1990). In the specimens studied the palpebral furrows are narrower forwards and distinctly wider backwards, a feature considered diagnostic of Berabichia (Geyer 1990: 78). As noted by Westrop \& Landing (2000: 873), there is only subtle difference in palpebral furrow morphology between some species of Berabichia and Antatlasia Hupé, 1953. Nevertheless, the species which Westrop \& Landing (2000) referred to (i.e. B. inopinata) was subsequently assigned to Epichalnipsus (see above) so that the palpebral furrow morphology can also be taken into consideration in the reassignment of the studied specimens to Berabichia. Morphometric analysis (see above) suggests that $C$. igrzycznae is a tectonically distorted morphological expression of $B$. oratrix. Other distinguishing features mentioned by Orłowski (1985: 245 ) in the original diagnoses have been caused by taphonomic processes (see above).

Berabichia oratrix is closest to $B$. subdita in most cranidial proportions and in the librigena (see Palmer \& Gatehouse 1972: pl. 2, fig. 12). A significant difference is an elongated posteriorly occipital ring and test ornamentation in B. subdita. The external moulds of $B$. oratrix do not show any evidence of the test's ornamentation or prosopon. Similar proportions occur also in the type species $B$. vertumnia; the only significant difference between them is the width of the fixigenae, which reach 50 $55 \%$ of posterior cranidial width in B. vertumnia, compared to almost $60 \%$ in B. oratrix. Compared with $B$. stenometopa, $B$. oratrix has a wider glabella at level of palpebral lobes, sagittally longer occipital ring, wider fixigenae and shorter palpebral lobes. Berabichia wilkesi is known from small, probably

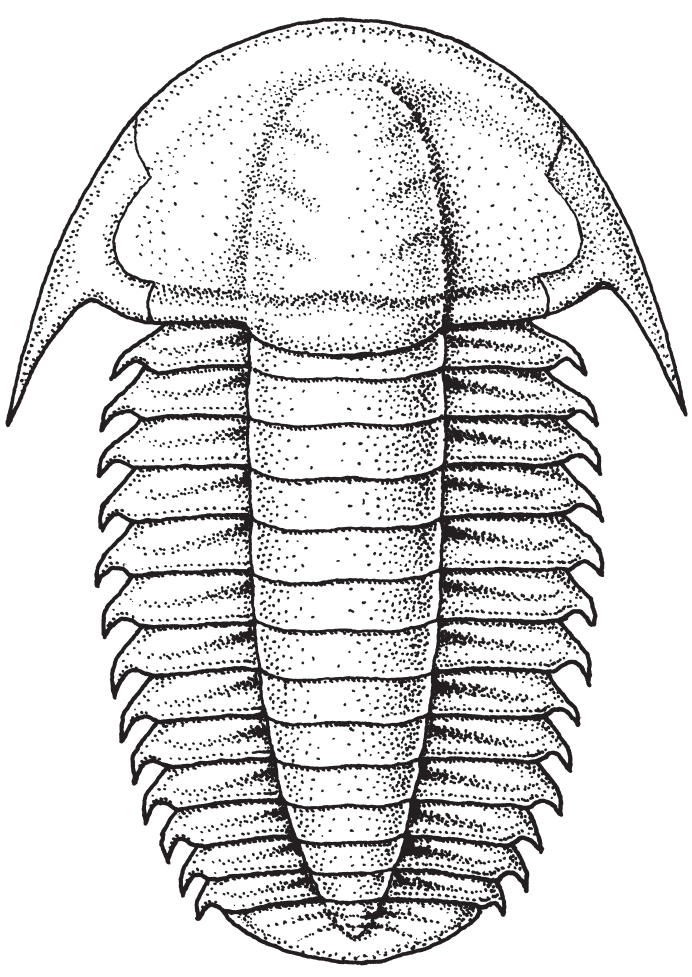

FIG. 17. - Reconstruction of Berabichia oratrix (Orłowski, 1985).

juvenile cranidia only, but the available specimens (Palmer \& Gatehouse 1972: pl. 9, figs 1, 2) are distinguished by distinct ocular ridges and a relatively wide anterior border. From B. erratica it differs in much wider fixigenae and longer palpebral lobes; moreover, $B$. erratica differs from other species of the genus in its trend to a sub-arcuate anterior margin of the cephalon. Berabichia rotundata is distinguished from the studied species by a relatively longer frontal area, a bluntly rounded anterior lobe of the glabella and a slightly wider and shallower occipital furrow (Ahlberg \& Bergström 1978: pl. 3, figs 1, 2).

\section{CONCLUSIONS}

Detailed study of specimens hitherto assigned to Comluella oratrix Orłowski, 1985 and Comluella igrzycznae Orłowski, 1985 has shown that they belong to the genus Berabichia Geyer, 1990. Application of 
bivariate and multivariate morphometric analyses, along with discrimination function provide evidence that the taxa are in reality conspecific and that the differences distinguishing the two morphotypes are caused by post-sedimentary processes, i.e. fossil preservation and tectonic distortion. The latter was confirmed by restoration of distorted specimens using graphic retrodeformation techniques after Srivastava \& Shah (2006). The studied specimens are thus assigned to Berabichia oratrix (Orłowski, 1985).

\section{Acknowledgements}

We dedicate this paper to Katarzyna Pawłowska, the daughter of Jan Czarnocki (1889-1951), an eminent Polish geologist working in the Holy Cross Mountains. Warm gratitude is expressed to Mark Webster (Chicago) for his critical but encouraging remarks on an earlier draft of the manuscript. The final version of the paper significantly gained from the constructive remarks of the journal reviewers, Gerd Geyer (Uppsala) and Nigel Hughes (Riverside), for which we are very grateful. Tatiana Woroncowa-Marcinowska (Museum of the Geological Survey, Warsaw) and Mariusz Niechwedowicz (Museum of the Faculty of Geology, Warsaw) kindly assisted with access to the specimens, and Katarzyna Skurczyńska-Garwolińska (Museum of the Geological Survey, Warsaw) helped with the photographs. Warm thanks are expressed to Bogusław Waksmundzki (Warsaw) for drawing the reconstruction and to Adam Halamski (Warsaw) for translating the abstract into French.

\section{REFERENCES}

Adrain J. M. 2011. - Class Trilobita Walch, 1771, in ZHANG Z.-Q. (ed.), Animal biodiversity: An outline of higher-level classification and survey of taxonomic richness. Zootaxa 3148: 104-109.

Ahlberg P. \& BergSTRÖM J. 1978. — Lower Cambrian ptychopariid trilobites from Scandinavia. Sveriges Geologiska Undersökning ser. Ca 49: 5-41.

Ahlberg P., Bergström J. \& JohAnsSON J. 1986. Lower Cambrian olenellid trilobites from the Baltic Faunal province. Geologiska Föreningens i Stockholm Förhandlingar 108: 39-56.
Belka Z., Ahrendt H., Franke W. \& Wemmer K. 2000. - The Baltica-Gondwana suture in central Europe: evidence from K-Ar ages of detrital muscovites and biogeographical data, in FrANKE W., HAAK V., OnCKen O. \& TANner D. (eds), Orogenic processes: quantification and modelling in the Variscan Belt. Special Publications of the Geological Society of London 179: 87-102.

Belka Z., Valverde-Vaquero P., Dörr W., Ahrendt H., Wemmer K., Franke W. \& SChäFer J. 2002. Accretion of first Gondwana-derived terranes at the margin of Baltica, in WinCHESTER J. A., PHARAOH T. C. \& Verniers J. (eds), Palaeozoic amalgamation of Central Europe. Special Publications of the Geological Society of London 201: 19-36.

Bergström J. \& Ahlberg P. 1981. - Upper Lower Cambrian biostratigraphy in Scania. Geologiska Föreningens i Stockholm Förhandlingar 103: 193-214.

BerTHELSEN A. 1992. - From Precambrian to Variscan Europe, in Blundell D., Freeman R. \& Muller S. (eds), A Continent Revealed: The European Geotraverse. Cambridge University Press, Cambridge: 153-164.

COOPER R. A. 1990. - Interpretation of tectonically deformed fossils. New Zealand Journal of Geology and Geophysics 33: 321-332.

CZARNOCKI J. 1919. - [Stratigraphy and tectonics of the Święty Krzyż Mountains]. Prace Towarzystwa Naukowego Warszawskiego 28: 1-172 (in Polish).

CZARNOCKI J. 1927. - [Cambrian and its fauna in the central part of the Holy Cross Mountains]. Sprawozdania Polskiego Instytutu Geologicznego 4: 189-207 (in Polish).

CZARNOCKI J. 1933. - [The scientific significance of Cambrian exposures in the vicinity of Ociesęki and Orłowiny]. Zabytki Przyrody Nieożywionej 2: 78-84 (in Polish).

Ebbestad J. O. R., Ahlberg P. \& Høyberget M. 2003. - Redescription of Holmia inusitata (Trilobita) from the Lower Cambrian of Scandinavia. Palaeontology 46: 1039-1045.

FORTEY R. A. 1990. - Ontogeny, hypostome attachment and trilobite classification. Palaeontology 33: 529-576.

Fortey R. A. \& Owens R. M. 1992. - The trilobite Angelina unstretched. Geology Today NovemberDecember: 219-221.

GĄGAŁA Ł. 2005. - Pre-Ordovician polyphase tectonics of the Cambrian sequences in the Kielce Unit, Holy Cross Mts. (Central Poland). Geological Quarterly 49: 53-66.

GEYER G. 1990. - Die marokkanischen Ellipsocephalidae (Trilobita: Redlichiida). Beringeria 3: 3-363.

GeYer G., Popp A., Weidner T. \& Förster L. 2004. New Lower Cambrian trilobites from Pleistocene erratic boulders of northern Germany and Denmark and their bearing on the intercontinental correlation. Paläontologische Zeitschrift 78: 127-136. 
Hammer Ø. \& Harper D. A. T. 2006. - Paleontological data analysis. Blackwell Publishing Ltd., Malden, USA, $351 \mathrm{p}$.

Hammer Ø., Harper D. A. T. \& Ryan P. D. 2001. Past: Paleontological Statistics Software Package for Education and Data Analysis. Palaeontologica Electronica 4 (1): 1-9.

Hughes N. C. 1994. — Ontogeny, intraspecific variation, and systematics of the Late Cambrian trilobite Dikelocephalus. Smithsonian Contributions to Paleobiology 79: 1-89.

Hughes N. C. 1999. - Statistical and imaging methods applied to deformed fossils, in HARPER D. A. T. (ed.), Numerical Palaeobiology. John Wiley \& Sons, Chichester: 127-155.

Hughes N. C. \& Jell P. A. 1992. - A statistical/computergraphic technique for assessing variation in tectonically deformed fossils and its application to Cambrian trilobites from Kashmir. Lethaia 25: 317-330.

Hughes N. C. \& Rushton A. W. A. 1990. — Computer-aided restoration of a Late Cambrian ceratopygid trilobite from Wales, and its phylogenetic implications. Palaeontology 33: 429-445.

Jell P. A. \& Adrain J. M. 2003. - Available generic names for trilobites. Memoirs of the Queensland Museum 48: 331-553.

KAESLER R. L. (ed.) 1997. - Treatise on Invertebrate Paleontology, Part O, Arthropoda 1, Trilobita, Revised. Geological Society of America, Boulder and University of Kansas Press, Lawrence: i-xxiv, 1-530.

KIÆR J. 1917. — The Lower Cambrian Holmia fauna at Tømten in Norway. Skrifter utgitt av Det Norske Videnskaps-Akademi i Oslo, I. Matematisk-naturvidenskapelig Klasse, 1916, 10: 1-140.

KRZYWIEC P., GUTOWSKI J., WALASZCZYK I., WRÓBEL G. \& WyBRANIEC S. 2009. - Tectonostratigraphic model of the Late Cretaceous inversion along the Nowe Miasto-Zawichost Fault Zone, SE Mid-Polish Trough. Geological Quarterly 53: 27-48.

KuteK J. \& GŁaZEK J. 1972. - The Holy Cross area, Central Poland, in the Alpine cycle. Acta Geologica Polonica 22: 603-652.

LAKE P. 1943. - Restoration of the original form of distorted specimens. Geological Magazine 80: 139-147.

ŁoBANOWSKI H. 1955. - [Stratigraphy of the Early Palaeozoic Deposits in the Eastern Part of the Daleszyce Basin in the Holy Cross Mts.] Unpublished M.Sc. Thesis, Faculty of Geology, University of Warsaw (in Polish).

MiZerSKI W., OrŁOWSKI S. \& RóżYCKI A. 1999. — [Tectonics of the Ociesęki and Zamczysko ranges in the Holy Cross Mountains]. Geological Quarterly 30: 187-200 (in Polish).

MoczYDŁOWSKA M. 1991. - Acritarch biostratigraphy of the Lower Cambrian and the PrecambrianCambrian boundary in southeastern Poland. Fossils and Strata 29: 1-127.
Nawrocki J., Dunlap J., Pecskay Z., Krzemiński L., ŻYlińSKa A., Fanning M., KoZŁowski W., SAlWa S., SZCZePanik Z. \& TRELA W. 2007. — Late Neoproterozoic to Early Palaeozoic palaeogeography of the Holy Cross Mountains (Central Europe): an integrated approach. Journal of the Geological Society of London 164: 405-423.

NAWROCKI J. \& POPRAWA P. 2006. - Development of Trans-European Suture Zone in Poland: from Ediacaran rifting to Early Palaeozoic accretion. Geological Quarterly 50: 59-76.

Nielsen A. T. \& Schovsbo N. H. 2011. - The Lower Cambrian of Scandinavia: Depositional environment, sequence stratigraphy and palaeogeography. EarthScience Reviews 107: 207-310.

OrŁOWSKI S. 1975. - [Cambrian and Upper Precambrian lithostratigraphic units in the Holy Cross Mts]. Acta Geologica Polonica 25: 431-448 (in Polish with English summary).

ORŁOWSKI S. 1985. - Lower Cambrian and its trilobites in the Holy Cross Mts. Acta Geologica Polonica 35: 231-250.

OrtowsKI S. 1987. - Stratigraphy of the Lower Cambrian in the Holy Cross Mountains, Central Poland. Bulletin of the Polish Academy of Sciences, Earth Sciences 35: 91-96.

OrŁOWSKI S. 1988. - Stratigraphy of the Cambrian System in the Holy Cross Mts. Geological Quarterly 32: 525-532.

OrŁOWSKI S. 1989. - Trace fossils in the Lower Cambrian sequence in Świętokrzyskie Mountains, Central Poland. Acta Palaeontologica Polonica 34: 211-231.

ORŁOWSKI S. 1992a. - Trilobite trace fossils and their stratigraphic significance in the Cambrian sequence of the Holy Cross Mountains, Poland. Geological Journal 27: 15-34.

ORŁOWSKI S. 1992b. - Cambrian stratigraphy and stage subdivision in the Holy Cross Mountains, Poland. Geological Magazine 129: 471-474.

ORłowSKI S. \& ZYLIŃSKA A. 2002. - Lower Cambrian trace fossils from the Holy Cross Mountains, Poland. Geological Quarterly 46: 135-146.

Palmer A. R. \& Gatehouse C. G. 1972. - Early and Middle Cambrian trilobites from Antarctica. Geological Survey of America Professional Papers 456 (D): 1-37.

Palmer A. R. \& Rowell A. J. 1995. - Early Cambrian trilobites from the Shackleton Limestone of the Central Transantarctic Mountains. The Paleontological Society Memoir 45: 1-28.

Ramsay J. G. \& Huber M. I. 1983. - The Techniques of Modern Structural Geology. Volume 1. Strain Analysis. Academic Press, London, 307 p.

Rushton A. W. A. \& SMith M. 1993. - Retrodeformation of fossils - a simple technique. Palaeontology 36: 927-930. 
SAMSONOWICZ J. 1959a. - On the Holmia-Fauna in the Cambrian of the Anticlinorium of Klimontów. Bulletin de l'Académie polonaise des Sciences, Série des sciences chimiques, géologiques et géographiques 7: 447-452.

SAMSONOWICZ J. 1959b. - On Strenuaeva from Lower Cambrian in Klimontów Anticlinorium. Bulletin de l'Académie polonaise des Sciences, Série des sciences chimiques, géologiques et géographiques 7: 521-524.

SAMSONOWICZ J. 1962. — Lower Cambrian fossils from the Klimontów anticlinorium in the Holy Cross Mts. Prepared for print from the deceased author's MS notes by K. Korejwo and L. Teller, in PASSENDORFer E. (ed.), Ksiega Pamiattowa ku czci Profesora Jana Samsonowicza. Wydawnictwa Geologiczne, Warszawa: 9-29.

SDZUY K. 1962. — Trilobiten aus dem Unter-Kambrium der Sierra Morena (S-Spanien). Senckenbergiana lethaea 43: 181-229.

SDZUY K. 1966. - An improved method of analysing distortion of fossils. Palaeontology 9: 125-134.

SHAW A. B. 1957. - Quantitative trilobite studies. II. Measurement of the dorsal shell of non-agnostidean trilobites. Journal of Paleontology 31: 193-207.

SRIVASTAVA D. C. \& SHAH J. 2006. - Digital method for strain estimation and retrodeformation of bilaterally symmetric fossils. Geology 34: 593-596.

STUDENCKI M. 1988. - [Sedimentary conditions of the Ociesęki Sandstone and Kamieniec Shale formations
(Lower Cambrian) in the Holy Cross Mountains]. Geological Quarterly 32: 533-540 (in Polish).

Webster M. 2009. - Ontogeny, systematics, and evolution of the effaced early Cambrian trilobites Peachella Walcott, 1910 and Eopeachella new genus (Olenelloidea). Journal of Paleontology 83: 197-218.

Webster M. \& Hughes N. C. 1999. - Compactionrelated deformation in well-preserved Cambrian olenelloid trilobites and its implications for fossil morphometry. Journal of Paleontology 73: 355-371.

Westrop S. R. \& Landing E. 2000. - Lower Cambrian (Branchian) trilobites and biostratigraphy of the Hanford Brook Formation, southern New Brunswick. Journal of Paleontology 74: 858-878.

ŻYLIŃSKA A. 2013. - The oldest Cambrian trilobites from the Holy Cross Mountains, Poland: taxonomic, stratigraphic and biogeographic reappraisal. Acta Geologica Polonica 63: 57-87.

ŻYLIŃSKA A. \& MASIAK M. 2007. — Cambrian trilobites from Brzechów, Holy Cross Mountains (Poland) and their significance in stratigraphic correlation and biogeographic reconstructions. Geological Magazine 144: 661-686.

ŻYLIŃSKA A. \& SZCZEPANIK Z. 2009. - Trilobite and acritarch assemblages from the Lower-Middle Cambrian boundary interval in the Holy Cross Mountains (Poland). Acta Geologica Polonica 59: 413-458. 